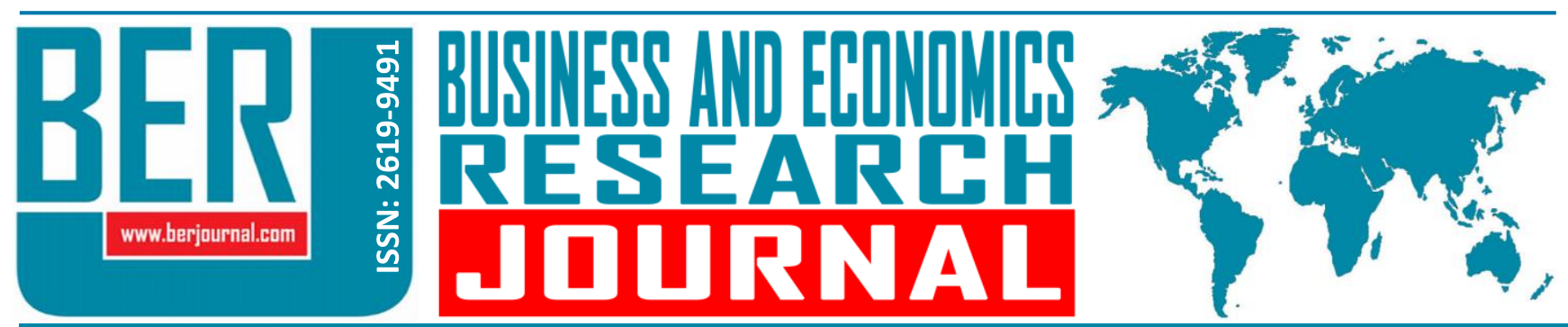

Business and Economics Research Journal Vol. 11, No. 4, 2020, pp. 1097-1117 doi: 10.20409/berj.2020.301

\title{
Kariyer Geleceği Algılamalarının İşveren Çekiciliği Algısına Etkisi $^{1}$
}

\author{
Berk Ozcinar $^{\mathrm{a}}$, Emel Esen $^{\mathrm{b}}$
}

Öz: İşletmelerin başarılı olabilmeleri için gereken en önemli faktörün insan kaynağı olduğu düşünüldügünde, kendini geliştirebilen, kariyerinde karşılaşacağı engellerle başa çıkabilen, değişimlere uyum sağlayabilen, belirsizliklerle başa çıkabilen ve geleceğe ilişkin olumlu bakış açısına sahip potansiyel çalışanları çekebilmek, işverenler açısından oldukça önemli bir hale gelmiştir. Çalışmada, kariyer geleceği algılamalarının, işveren çekiciliği algısına etkisini ölçmek amaçlanmıştır. Bu amaçla, 361 katılımcıya anket uygulanmıştır. Kariyer geleceği algısının ölçümünde Rottinghaus vd. (2005) tarafından oluşturulan "kariyer geleceği ölçeği"nden, işveren çekiciliği algısının ölçümünde ise Berthon vd. (2005) tarafından oluşturulan "işveren çekiciliği ölçeği"nden yararlanılmıştır. Araştırmanın bulgularına göre kariyer geleceği algısının, işveren çekiciliğinin özellikle gelişim değeri, sosyal değer ve fayda değerini pozitif yönde etkilediği, ekonomik değeri ise negatif yönde etkilediği ortaya konmuştur. Aynı zamanda cinsiyet, kuşak, çalışma durumu ve öğrenim durumuna göre kariyer geleceği algılamaları ve işveren çekiciliği algılamalarında farklılıklar olduğu saptanmıştır.

\section{Effect of The Career Future Perceptions on Employer Attractiveness Perceptions}

Abstract: When considering the human resource is the most important factor to be successful for the companies today, attracting the potential employees who are able to improve themselves, cope with the obstacles that will meet along with his or her careers, adapt to changes, struggle with uncertainties, have a positive perspective for future has become rather important. In the study, it was aimed to measure the effect of the levels of perception of generations career future on employer attractiveness. For this purpose, a survey was conducted with 361 participants. In the measurement of career future perception, "career future scale" developed by Rottinghaus et al. (2005) was used and in the measurement of employer attractiveness, the "employer attractiveness scale" developed by Berthon et al. (2005) was used. According to the results obtained by the conducted research, it is realized that the perception of career future affects especially improvement value, social value, and benefit value of employee attractiveness positively and affects economic value negatively. It was also found that there are differences in career future perceptions and employer attractiveness according to gender, generation, employment status, and education level.

Anahtar Sözcükler: Kariyer Geleceği Algısı, Kariyer Uyumluluğu, Kariyer İyimserliği, İşveren Çekiciliğ

JEL: M10, M19

$\begin{array}{ll}\text { Geliş } & : 12 \text { Temmuz } 2020 \\ \text { Düzeltme } & : 19 \text { Ağustos } 2020 \\ \text { Kabul } & : \text { :04 Eylül } 2020 \\ & \\ \text { Tür } & : \text { Araştırma }\end{array}$

Keywords: Career Future Perception, Career Adaptation, Career Optimism, Employer Attractiveness

JEL: M10, M19

$\begin{array}{ll}\text { Received } & : 12 \text { July } 2020 \\ \text { Revised } & : 19 \text { August } 2020 \\ \text { Accepted } & : \text { : } 4 \text { September } 2020 \\ \text { Type } & : \text { Research }\end{array}$

a Master Student, Yildiz Technical University, Social Sciences Institute, Istanbul, Turkiye, berkozcinar@gmail.com (ORCID ID: 00000002-1521-6635)

b Assoc. Prof., PhD., Yildiz Technical University, Faculty of Economics and Administrative Sciences, Business Administration Department, Istanbul, Turkiye, emeloz@yildiz.edu.tr (ORCID ID: 0000-0001-5753-3252) 


\section{Giriş}

Birbirlerine yakın niteliklerde ve benzer kaynaklara sahip olan işletmeler rakiplerinden, nitelikli insan kaynakları aracılığı ile farklılaşabilirler. Bu nedenle gerek mevcut çalışanları elde tutmak gerekse potansiyel çalışanların işletmeye çekmek sürdürülebilir başarı için önem kazanmıştır. Nitelikli çalışan bulmanın zorluğu, işletmeleri çalışanlar için çekici bir yer olmaya zorlamaktadır. İşletmeler nitelikli iş gücünü çekebilmek için potansiyel çalışanlarda işveren çekiciliği algısı yaratmalıdır. Bu nedenle işletmeler için potansiyel çalışan durumunda olan $Y$ ve $Z$ kuşağındaki bireylerin işverenlere yönelik beklentilerinin, değerlerinin ve amaçlarının bilinmesi ve bunlar doğrultuda bir işveren markası oluşturulması gereklidir. Potansiyel çalışanları çekmek ve mevcut çalışanların organizasyona bağlılığını sağlamak için başarılı bir işveren markası yaratmak gerekmektedir (Barrow ve Mosley, 2011: 164). İşveren markasının en önemli çıktılarından biri de işveren çekiciliğidir (Backhaus ve Tikoo, 2004). İ̧̧veren markalaşması sürecindeki faaliyetlerin potansiyel çalışanlarda fonksiyonel ve sembolik çağrışımlara sebep olduğu ve bu durumun işveren imajını çizdiği belirtilmiştir. Bu çağrışımlar işveren tarafından kontrol edilemeyen bilgi kaynaklarından elde edilebileceği gibi işveren markası tarafından tasarlanan ve kontrol edilen mesajlar da olabilmektedir. Bu çağrışımlar sonucu oluşan olumlu işveren imajı da işveren çekiciliğine yol açmaktadır. Bununla birlikte, adaylar; nitelikleri, bilgileri, güçlü-zayıf yönleri, ilgi alanları ve iş fırsatları doğrultusunda kariyerlerini planlarlar. Bireylerin çalışma hayatında başarılı olabilmeleri; kariyerlerini etkili bir şekilde yönetebilme, sürekli olarak kendilerini geliştirebilme, iş hayatında oluşabilecek değişimlere uyum sağlayabilme, iş dünyasındaki değişen taleplerini karşılayabilme ve belirsizlikleri tolere edebilmeleri gibi birçok faktöre bağlıdır (Rottinghaus vd., 2005). Kariyer geleceğine ilişkin olumlu bakış açısı olan potansiyel çalışanların hem kendi kariyerlerinde başarılı olması hem de çalıştığı işletmenin başarısına katkı sağlayacak olması muhtemeldir. Bu nedenle olumlu kariyer geleceği algısına sahip potansiyel çalışanları, işverenlerin ortaya koymuş olduğu izlenimler etkileyecektir.

Çalışmada yakın zamanda çalışma hayatına girecek olan üniversite öğrencileri ile çalışma hayatına başlayan yeni mezunların kariyer geleceği algılarının işveren çekiciliği algısına etkisi araştııılmıştır. Çalışmanın teorik bölümünde kariyer geleceği algısı ve işveren çekiciliği kavramlarına değinilmiş, uygulama bölümünde ise çalışmanın amacı ve araştırma modeli kapsamında yapılan nicel araştırmaya değinilmiştir. 361 katılımcı ile gerçekleştirilen anketten elde edilen veriler doğrultusunda, kariyer geleceği algısının işveren çekiciliği algısına etkisi ve değişkenlerin birbirleriyle olan ilişkisi incelenmiştir. Sonuç kısmında ise elde edilen bulgulara ilişkin tartışmalara yer verilerek, çalışmanın sınırlarından ve önerilerden bahsedilmiştir.

\section{Kavramsal Çerçeve}

Bu bölümde, çalışmanın değişkenleri olan kariyer geleceği algılamaları ve işveren çekiciliği algısı kavramları ile bu kavramların ilişkisine dair incelemelere yer verilmiştir.

\subsection{Kariyer Geleceği Algısı}

Kariyer geleceği algıSı, Rottinghaus vd. (2005) tarafından bireylerin gelecekteki kariyer planlamalarına yönelik tutumlarını içeren bir kavram olarak tanımlanmıştır. Kariyer uyumluluğu, kariyer iyimserliği ve iş piyasasına ilişskin algılanan bilginin, bu kavramı oluşturan ve ölçümlerde kullanılan önemli kavramlar olduğu bilinmektedir. Kariyer uyumluluğunun temellerini Super (1955), Super ve Knasel (1981)'in çalışmalarının oluşturduğu ve kariyerimiz hakkında neye ihtiyaç duyduğumuzu açıklayan bir yapı olduğunu söylemek mümkündür. Bu açıdan kariyer uyumluluğunun; kariyer dayanıklılı̆ı, kariyer gelişimi, kariyer olgunluğu gibi kavramlardan farklılıkları bulunmaktadır. Kariyer iyimserliğinde de Scheier ve Carver (1985)'ın ortaya koyduğu gibi iyimserliğin, kariyer planlama stratejilerini etkilediği ve bu sayede daha iyi kariyer yönetimi sağladığı ortaya çıkmıştır. İş piyasası ile değerlendirmelerde de, işten ve işletmeden beklentiler ile elde edilecek faydalar incelenmiştir.

\subsubsection{Kariyer Uyumluluğu}

Kariyer uyumluluğu kavramı ilk olarak Super (1980) tarafından kariyer olgunluğu ifadesi, kariyer gelişimi ile ilgili çalışmalarda kullanıımıştır. Kariyer uyumu, bireylerin sahip olduğu meslekler arasındaki geçişlerin kolaylığı anlamına gelen bir ifadedir. Diğer bir deyiş̧le, bireyin kariyerine katkı sağlayacak görevleri 
yaparken, aynı zamanda çalışma koşullarından ve iş hayatından kaynaklanan zorlukların üstesinden gelebilmesi anlamına gelir (Savickas, 1997: 254). Super ve Knasel (1981: 196) mesleki ilgi ve yeteneklerin keşfedildiği ergenlik dönemi ile kariyer başarısının devam ettiği yetişkinlik dönemini incelemişler ve kariyer uyumunu bu evreler arasında mesleki hayatta karşılaşılan değişikliklerle baş etmeye hazır bulunma olarak tanımlamışlardır. Savickas (1997: 254) kariyer uyumu kavramını, bireyin kariyerine hazırlanırken karşılaşması muhtemel görevlerle ve iş hayatından kaynaklanan sürpriz değişimlerle başa çıkma gücü olarak tanımlamıştır. Kariyer uyumu kavramı yapılan sonraki çalışmalarda geliştirilmiş ve genellikle bireyin meslek hayatında beklenen durumlarla ve beklenenden iyi veya kötü olası durumlarla baş edebilmesi olarak ifade edilmiştir (Savickas ve Porfeli, 2012: 661). Rottinghaus vd. (2005: 4) kariyer uyumunu değişimle başa çıkma ve bundan yararlanma, tahmin edilemeyen olaylar olduğunda ise bununla başa çıkma olarak tanımlarken; Rottinghaus ve Van Esbroeck (2011: 35) bu tanımı bireysel farklııkları destekleyen, uyum ve mesleki gelişim için etkin bir süreç olarak güncellemiştir. Kariyer uyumu ilgi, kontrol, merak ve güven olmak üzere dört temel tutumdan oluşmaktadır (Savickas ve Porfeli, 2012: 663).

\subsubsection{Kariyer İyimserliği}

Pozitif psikoloji alanında önemli katkıları olan Seligman (2006) iyimserlik kavramını, kişinin gelecekte kendi yaşamında iyi şeyler olacağına dair inancı olarak tanımlamıştır. İyimserlik, karşılaşılan olumsuz olayları geçici, dışsal ve durumsal sebeplere bağlayan, olumlu olayları ise kalıcı, içsel ve genel sebeplere bağlayan bir bakış açısı olarak görülmektedir (Seligman, 1998: 43). İyimser bireyler, işlerin yolunda gideceğini umarlar ve genellikle kötü şeylerden ziyade iyi şeylerin olacağını düşünürler. Kötümser bireyler ise işlerinin yolunda gitmeyeceğini düşünürler ve kötü sonuçlar bekleme eğiliminde olurlar (Scheier ve Carver, 1985: 219). İyimser bireyler önüne engeller çıktığında bile hedefe ulaşmak için çabalarını sürdürürken, kötümser bireyler pes etme eğilimi göstermektedir (Crane ve Crane, 2007: 15).

Kariyer iyimserliği kavramı ise bireyin gelecekteki kariyer gelişimi ile ilgili olumlu sonuçlar elde edeceği beklentisi içinde olması ya da olayların en olumlu yönlerine vurgu yapması ve kariyer planlama sürecinde kendini rahat hissetmesi olarak tanımlanmaktadır (Kalafat, 2012: 171). Scheier vd. (1994: 1063)'e göre kariyer iyimserliği, bireyin mesleki hayatında oluşan problemler karşısında olumlu sonuçlar alacağına ilişkin olumlu bir beklenti içinde olmasıdır. Rottinghaus vd. (2005: 5-6) ise kariyer iyimserliğini bireylerin gelecekte kariyerleri için en iyi durumu beklemeleri, olumsuz duygulardan kaçınmaları olarak tanımlamaktadırlar. Kariyer iyimserliği, kişinin gelecekteki kariyer gelişimiyle ilgili sürekli olumlu sonuçlar elde edeceği beklentisi içinde olması veya olayların en olumlu yönlerine vurgu yapması bu nedenle de kariyer planlama sürecinde kendini rahat hissetmesi şeklinde ifade edilmektedir (Kalafat, 2012: 171). Kariyer uyumunda başarının yakalanması için en önemli kaynak etkin bir kariyer iyimserliğidir (Rottinghaus vd., 2005: 5). Kariyer iyimserliğini yakalamış kişilerin benlik saygılarının daha yüksek olduğu, problem çözme becerilerinin bulunduğu, kariyerleri hakkında özgüvene sahip olan hedef odaklı ve psikolojik sorunları olmayan kişilerdir (Aspinwall vd., 2001: 218).

\subsection{3. İs Piyasasına ilişskin Algılanan Bilgi}

İs piyasasına ilişkin algılanan bilgi, bireyin iş piyasası ve istihdam eğilimlerini ne kadar iyi anladığı konusundaki algıdır (Rottinghaus vd., 2005: 8). Bireyin işten ve işletmeden beklentilerinin, işletmenin bireyden beklentilerinin, işin ekonomik getirisinin, sosyal yaşamına uygunluğunun ve bireye sağlanacak katkıların bilinmesi bireyin alacağı karara doğrudan etki etmektedir. Bu çerçevede iş piyasasındaki eğilimlerin farkında olunması, teknolojik değişimlerin takip edilebilmesi, kariyer fırsatı yaratabilecek ekonomik göstergelerin ele alınması, ilgi çeken bir meslek veya sektörün varlığı gibi konular ön plana çıkmaktadır (Rottinghaus vd., 2012: 130). Genel olarak, iş piyasasıyla ilgili yeterli bilgi sahibi olan bireylerin, kariyerleri ile ilgili daha iyi karar verebildikleri görülmüştür (Gunkel vd., 2010: 521). 


\section{2. İşveren Çekiciliği Algısı}

Literatürde ilk olarak Ambler ve Barrow (1996: 187) kullanılan işveren markası kavramı; "bir işletme tarafından istihdam yoluyla sağlanan fonksiyonel, ekonomik ve psikolojik faydalar bütünü" olarak tanımlanmıştır. Fonksiyonel faydalar (kariyer gelişimi, eğitim gibi) ve ekonomik faydalar (ücret, yan hakları, ödül vs.) somut kavramları içerirken, psikolojik faydalar ise çalışanların herkesten saygı görmeleri, yönetimin objektifliği, özgür ifade ortamı, olumlu ilişkiler kurabilme, kendini ifade edebilme, mutlu bir çalışma ortamının olması gibi soyut kavramları içermektedir. Backhaus ve Tikoo (2004: 502) işveren markasını, "bir işletmenin kendini işveren olarak en çekici yapan özellikleriyle ilgili net bir algı meydana getirmek için kurum içinde ve dışında sürdürülen çabalar" olarak tanımlamıştır. İşveren markalaşması yoluyla uygulanan faaliyetler sonucunda, potansiyel çalışanlar üzerinde oluşan pozitif izlenimler işveren çekiciliği sağlamaktadır (Öksüz, 2012: 24). Nitelikli çalışanların, çalışacakları işletmeleri ve ne kadar süre çalışacaklarını belirleyen taraf olması ile işletmelerin potansiyel çalışanlara karşı işveren çekiciliği sağlaması zorunluluğu ortaya çıkmıştır (Kaliprasad, 2006: 22). İşletmelerin güçlü bir işveren markası yaratabilmeleri sonucunda, sundukları duygusal ve fonksiyonel faydalar artacak ve potansiyel çalışanların işletmeyi çekici olarak algılamasına yol açacaktır (Berthon vd., 2005: 154).

Potansiyel çalışanların işletmeye başvurmaya ve katılmaya yönelik isteklerinin oluşumunda öne çıkan en önemli faktörlerden biri işveren çekiciliğidir (Highhouse vd., 2003: 9). İşveren markalaşması sonucunda "çalışılabilecek en iyi yer" olarak algılanan işletme, potansiyel çalışanlara büyük ölçüde çekici gelecektir. Bu nedenle adaylar, işveren çekiciliğine sahip olan işletmelerin iş tekliflerini daha kolay kabul edeceklerdir (Berthon vd., 2005: 154). Highhouse vd. (2003: 989), işveren çekiciliği kavramını "bireylerin potansiyel olarak istihdam edileceği şirketlere karşı duygusal ve tutumsal düşüncelerinin yansıması" olarak tanımlamıştır. Berthon vd. (2005: 156) ise, işveren çekiciliğini, "potansiyel bir çalışanın belirli bir organizasyonda çalışması durumunda öngördüğü faydalar" olarak tanımlamıştır. İşveren çekiciliğinin, işveren markası değerinin bir öncüsü olduğu ve potansiyel çalışanların işvereni ne kadar çekici algılarlarsa marka değerinin de o kadar güçlü olacağını belirtmişlerdir. Jiang ve lles (2011: 106), işveren çekiciliğini başvuranların dikkatini bir işveren markasına odaklamak ve mevcut çalışanları kalmaya teşvik etmek olarak tanımlayıp, iç çekicilik ve dış çekicilik olmak üzere iki boyuta ayrıldığını ifade etmişlerdir. İç çekicilik mevcut çalışanların algıları, duyguları ve nitelikleriyle ilişkiliyken, dış çekicilik ise potansiyel çalışanların algıları, duyguları ve niteliklerinden meydana gelmektedir. Sullivan (2004) organizasyonların çalışanlar tarafından çekici ve "çalışmak için harika bir yer" olarak görülebilmesi için çeşitli yönetim ve insan kaynakları uygulamalarının ortaya konulması gerektiğini savunmuştur.

Günümüzde dünyanın dört bir yanındaki ülkeler, üniversiteler ve şirketler, çeşitli alanlardaki yüksek vasıflı çalışanları kendilerine çekebilmek için birbirleriyle rekabet etmektedirler (Mahroum, 2000: 29). Ambler ve Barrow (1996: 186), en kalifiye adayların başvurularını çekebilen işverenlerin en iyi insan kaynaklarına sahip olacağını ve en iyi insan kaynaklarının da en iyi ürün ve hizmetleri ortaya çıkartarak rekabet üstünlüğü sağlayacağını dile getirmişlerdir. İşletmeler, nitelikli insan kaynaklarına olan ihtiyacın artmasıyla kalifiye potansiyel çalışanları çekebilmek için daha çok kaynak ayırmaya başlamışlardır. İnsan kaynakları bütçelerinin büyük bir kısmını işe alım ve çalışanı elde tutma faaliyetlerine ayırmaktadırlar. Daha nitelikli çalışanları çekebilen işverenler, işe alım sürecinde daha büyük bir potansiyel çalışan havuzuna sahip olacağından hem işe alım maliyetleri düşecek hem de kendisine uygun nitelikte çalışan bulması kolaylaşacaktır (Turban, 2001: 293).

Berthon vd. (2005) yaptıkları çalışma sonucunda, potansiyel çalışanlar için işveren çekiciliği sağlayan beş boyut belirlemişlerdir. Bu bileşenler; sosyal değer boyutu, fayda değeri boyutu, ekonomik değer boyutu, gelişim değeri boyutu ve uygulama değeri boyutudur.

- Sosyal Değer Boyutu: Eğlenceli ve mutlu bir çalışma ortamının varlığı, çalışma arkadaşları ve yöneticiler ile iyi ilişkileri, uyumlu çalışma atmosferini kapsayan bir boyuttur.

- Fayda Değeri Boyutu: İşverenin potansiyel çalışanların heyecan verici çalışma ortamı ve yeni çalışma uygulamaları sağlayan, yenilikçi ürün ve hizmetler üretmek için çalışanın yaratıcılığından yararlanan örgütlere ilişkin çekicilik algısının oluştuğu boyuttur. 
- Ekonomik Değer Boyutu: Potansiyel çalışanlar tarafından ortalamanın üzerinde bir maaş, yan haklar, terfi imkanları ve iş güvencesinin çekici olarak değerlendirildiği boyuttur.

- Gelişim Değeri Boyutu: Çalışanlara kendini geliştirme, gelecekteki kariyer hedeflerine ulaşmayı sağlama, tanınma ve deneyim kazanma imkânı sunulan boyuttur.

- Uygulama Değeri Boyutu: İşverenin müşteri odaklı ve insancıl bir çalışma ortamı sunması, çalışanlara öğrendiklerini uygulama ve başkalarına öğretme imkânı vermesini içeren boyuttur (Berthon vd., 2005: 159-162).

İşveren çekiciliği algılamalarının tespitinde bu boyutlar değerlendirmeye alınacak olup, bununla birlikte demografik farklııklar incelenecektir. Manpower Yetenek Açığı 2020 araştırmasında, çekicilik unsurları olan ücret, esnek çalışma saatleri, rekabetçi bir iş, kariyerde ilerleme imkânı, yetenekleri geliştirme, ideal bir iş yeri gibi unsurların sıralamasının kuşaklara, cinsiyete ve eğitim durumuna göre değiştiği ortaya konmuştur.

\subsection{Kariyer Geleceği Algısına İlişkin Çalışmalar ve İşveren Çekiciliği Algısı ile ilişkisi}

Kariyer geleceği algısı kavramını ele alan çalışmalardan bazıları kariyer uyumluluğu ve kariyer iyimserliği değişkenlerini ayrı ayrı ele alırken, bazıları ise kariyer geleceği algısı boyutlarını birlikte ele alarak farklı değişkenlerle arasındaki ilişkileri incelemişlerdir. Yapılan çalışmalara Tablo 1'de yer verilmiştir.

Tablo 1. Kariyer Geleceği Algısına İlişkin Çalışmalar

\begin{tabular}{|c|c|}
\hline Yazar/Yazarlar & Çalışmanın Konusu \\
\hline Rottinghaus vd. (2005) & $\begin{array}{l}\text { Bireylerin kariyer planlamalarına ilişkin tutumlarını değerlendirmek üzere } \\
\text { yapılan çalışma } 690 \text { lisans öğrencisi ile gerçekleştirilmiş ve } 25 \text { soruluk "kariyer } \\
\text { geleceği ölçeği" oluşturulmuştur. Bu ölçek; kariyer uyumu, kariyer algısı ve } \\
\text { algılanan bilgi olmak üzere üç boyuttan oluşmaktadır. }\end{array}$ \\
\hline Mcllveen vd. (2013) & $\begin{array}{l}529 \text { üniversite öğrencisinin kariyer iyimserliği ve memnuniyet düzeyleri } \\
\text { arasındaki ilişki incelenmiştir. Kariyer iyimserliğinin ölçümünde "kariyer } \\
\text { geleceği ölçeği" (Rottinghaus vd., 2005) kullanıımıştır. Öğrencilerin akademik } \\
\text { memnuniyet düzeyleri ile kariyer iyimserliği algıları arasında pozitif yönde bir } \\
\text { ilişki tespit edilmiştir. }\end{array}$ \\
\hline Kalafat (2014) & $\begin{array}{l}\text { Araştırma } 555 \text { üniversite öğrencisi ile yapılmış olup, "kariyer geleceği ölçeği" } \\
\text { (Rottinghaus vd. 2005) kullanılmıştır. Kariyer iyimserliği ve kariyer } \\
\text { uyumluluğu kavramlarının, deneyime açıklık ve sorumluluk özellikleri ile } \\
\text { pozitif yönde pozitif ilişki içinde olduğu görülmüştür. }\end{array}$ \\
\hline Zorver ve Owen (2014) & $\begin{array}{l}\text { İki farklı çalışma grubundan oluşan üniversite son sınıf öğrencileri ile yapılan } \\
\text { çalışmada okuldan işe geçiş sürecindeki bireylerin kariyer uyumu ve kariyer } \\
\text { iyimserliği ölç̧en "kariyer uyumluluğu ve kariyer iyimserliği ölçeği (KUiO)" } \\
\text { geliştirilmiştir. }\end{array}$ \\
\hline $\begin{array}{l}\text { Tladinyane ve Merwe } \\
\text { (2015) }\end{array}$ & $\begin{array}{l}\text { Kariyer uyumluluğu ve işe tutkunluğun yaş ve ırk açısından farklılık gösterip } \\
\text { göstermediğini araştırmak amacıyla } 131 \text { çalışan ile yapılan araştırmada veri } \\
\text { toplama aracı olarak "Kariyer Uyum Ölçeği" (Savickas ve Porfeli, 2012) } \\
\text { kullanılmıştır. Yaş ve ırk değişkenlerinin çalışanların kariyer uyumluluğunu ve } \\
\text { tutkunluğu arttırmada önemli faktörler olduğu ortaya konulmuştur. }\end{array}$ \\
\hline Zacher vd. (2015) & $\begin{array}{l}\text { Kariyer uyumu ve çalışanın örgütte kalma niyeti (yeni kariyer fırsatlarını takip } \\
\text { etme algısı yetersizliği veya isteksizliği) arasındaki ilişki incelenmiştir. } \\
\text { Araştırma Brezilya'daki } 404 \text { çalışan ile gerçekleştirilmiştir. Kariyer geleceği } \\
\text { algısı ile örgütten ayrılma niyeti arasında negatif yönde bir ilişki olduğu ortaya } \\
\text { konmuştur. }\end{array}$ \\
\hline
\end{tabular}


Tablo 1. Kariyer Geleceği Algısına İlişkin Çalışmalar (Devamı)

\begin{tabular}{|c|c|}
\hline Santilli vd. (2016) & $\begin{array}{l}\text { İtalya ve Isviçre'de } 12-16 \text { yaş arasındaki } 1259 \text { gençüzerinde yapılan çalışmada } \\
\text { kariyer uyumluluğu, umut, iyimserlik ve yaşam memnuniyeti arasındaki } \\
\text { ilişskiler incelenmiştir. Veri toplama aracı olarak "Kariyer Uyum Ölçeği" } \\
\text { (Savickas ve Porfeli, 2012) kullanılmıştır. Kariyer uyumluluğunun yaşam } \\
\text { memnuniyeti üzerinde etkisi olduğu ve geleceğe karşı yönelimin aracı } \\
\text { değişken olduğu tespit edilmiştir. }\end{array}$ \\
\hline Siyez ve Belkıs (2016) & $\begin{array}{l}\text { Üniversite öğrencilerinde kariyer uyumluluğu ve kariyer iyimserliği ile } \\
\text { toplumsal cinsiyet algısı arasındaki ilişki incelenmiştir. Araştırmaya } 2255 \\
\text { öğrenci katılmışır. Veri toplama aracı olarak "Kariyer Geleceği Ölçeği" } \\
\text { (Rottinghaus vd. 2005) kullanılmıştır. Kariyer uyumluluğu ve kariyer } \\
\text { iyimserliği ile toplumsal cinsiyet algısı arasında pozitif yönde anlamlı bir ilişki } \\
\text { olduğu tespit edilmiştir. }\end{array}$ \\
\hline $\begin{array}{l}\text { Sökmen ve Aydıntan } \\
\text { (2016) }\end{array}$ & $\begin{array}{l}\text { Kariyer geleceği algısının iş tatmini ve işten ayrılma niyeti üzerindeki etkisi } \\
\text { araştırılmıştır. Araştırma örneklemi kamu işletmesinde çalışan } 196 \text { kişiden } \\
\text { oluşmaktadır. "Kariyer Geleceği Ölçeği” (Rottinghaus vd., 2005) kullanılmıstır. } \\
\text { Kariyer uyumluluğu ve kariyer iyimserliğinin iş tatmini üzerinde pozitif ve } \\
\text { anlamlı bir etkisi olduğu, işten ayrılma niyeti üzerinde ise negatif bir etkisi } \\
\text { olduğu görülmüşsür. }\end{array}$ \\
\hline Karadaş vd. (2017) & $\begin{array}{l}\text { Hemşirelik öğrencilerinin kariyer planlamaya ilişkin görüšlerini araştırmak } \\
\text { amaçlanmıştır. Araştırma verileri "Kariyer Geleceği Ölıceği” (Kalafat, 2012) ile } \\
\text { toplanmışır. Hemşirelik öğrencilerinin kariyer uyumluluğu ve kariyer } \\
\text { iyimserliği düzeylerinin yüksek, iş piyasasına ilişkin algılanan bilgilerinin ise } \\
\text { orta düzeyde olduğu ortaya çıkmıştır. }\end{array}$ \\
\hline McLennan vd. (2017) & $\begin{array}{l}\text { Lisans eğitimi almakta olan } 402 \text { öğretmen adayı ile yapılan araştırmada } \\
\text { adayların özyeterliliklerinin kariyer iyimserliği ve kariyer uyumluluğu ile ilişkisi } \\
\text { araştııılmışı̆ı. Veri toplama aracı olarak; "Kariyer Uyumu Ölçeği” (Savicaks ve } \\
\text { Porfeli, 2012) ve "Kariyer Geleceği Ölçeği" (Rottinghaus vd., 2005) } \\
\text { kullanılmıştır. Öğretmen adaylarının özyeterliliklerinin kariyer iyimserliklerini } \\
\text { doğrudan etkilediği, kariyer uyumluluğunun üzerinde ise aracı etkisi olduğu } \\
\text { ortaya çıkarılmışır. }\end{array}$ \\
\hline Kalafat (2018) & $\begin{array}{l}\text { Araştırmada öğrencilerin kariyer uyumluluğu ve kariyer iyimserliği ile } \\
\text { psikolojik dayanıklıık ve özyeterlilik arasındaki ilişkiler incelenmiştir. } \\
\text { Araştırmaya yaşları } 21-30 \text { arasında değişen } 177 \text { kişi katılımıştır. Cinsiyetin } \\
\text { kariyer uyumluluğunda bir farklıı göstermezken, kariyer iyimserliği } \\
\text { konusunda kadınların daha pozitif bir tablo çizdiği görülmüşşür. Psikolojik } \\
\text { dayanıklılık, kendini beğenme ve özyeterlilik kavramlarını kariyer } \\
\text { uyumluluğunu pozitif yönde etkilediğg, kariyer iyimserliğinin ise yalnızca } \\
\text { özyeterlilik kavramı ile pozitif bir ilişki içinde olduğu ortaya konulmuştur. }\end{array}$ \\
\hline
\end{tabular}

Tablo 1'de yer alan çalışmalarda da desteklendiği üzere cinsiyet, eğitim, yaş ve çalışma durumuna göre, kariyer geleceği algılamalarının ve boyutlarının da farklılaştığı görülmüştür.

$\mathrm{Bu}$ çalışmada, kariyer geleceği algılarının işveren çekiciliği algısına etkisinin incelenmesi amaçlanmaktadır. Tüm bu değerlendirmeler neticesinde, aşağıdaki hipotezler geliştirilmiştir.

\section{H1: Kariyer geleceği algıları işveren çekiciliği algısını etkilemektedir.}

H1a: Kariyer uyumluluğu, işveren çekiciliği algısını etkilemektedir.

H1b: Kariyer iyimserliği, işveren çekiciliği algısını etkilemektedir.

H1c: Iş̧ piyasasına ilişsin algılanan bilgiler, işveren çekiciliği algısını etkilemektedir.

Bu hipotezlerle birlikte farklı demografik özelliklere göre (cinsiyet, kuşak, çalışma durumu ve öğrenim durumu gibi) kariyer geleceği algısı ve işveren çekiciliği algısındaki farklılıklar da araştırma sorusu olarak ele alınmıştır. 


\section{Araştırma Yöntemi}

\subsection{Araştırmanın Amacı ve Önemi}

Insan kaynağının işletmeleri birbirinden farklılaştıran bir kavram haline gelmesiyle birlikte, nitelikli potansiyel çalışanların işe alımı konusunda işverenler birbirleriyle rekabete girmeye başlamışlardır. Çalışanlar gözünde "çalışılabilecek bir yer" olarak algılanmak ve çekici bulunmak, işletmeleri rakiplerinden avantajlı hale getirecektir. Çalışanların işveren çekiciliği boyutlarına verdikleri önem gerek bireysel gerekse örgütsel birçok faktörden etkilenmektedir. Araştırma, bireysel faktörlerden biri olan ve bireyin kariyerini etkili bir şekilde yönetebilmesini, kendini geliştirebilmesini ve değişimlere uyum sağlayabilmesini etkileyen kariyer geleceği algısının işveren çekiciliği algısına etkisini araştırmaktadır. Yapılan literatür araştırması sonucunda, kariyer geleceği algısı kavramına ilişkin insan kaynakları alanında yapılan çalışmaların az oluşu ve bu kavram ile işveren çekiciliği arasındaki ilişkiyi inceleyen bir çalışmaya rastlanılmamış olması nedeniyle çalışmanın literatüre katkı sağlayacağı düşünülmektedir.

\subsection{Araștırma Modeli}

Araştırmada, kariyer geleceği algılarının, işveren çekiciliği algısına etkisi incelemiştir. Kariyer geleceği algısı bağımsız değişken iken, işveren çekiciliği algısı ise bağımlı değişken olarak ele alınmıştır. Araştırma modeli Şekil 1'de gösterilmiştir.

Şekil 1. Araştırma Modeli

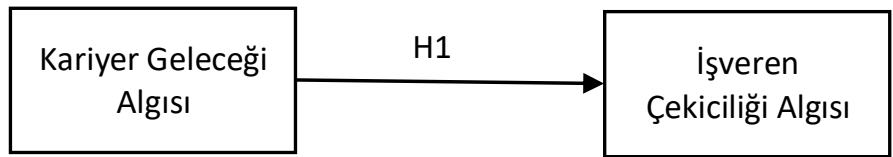

\section{3. Örneklem}

İstanbul'da üniversite öğrenimi görmekte olan ve öğrenimini tamamlayıp çalışma hayatına başlayan 408 kişiye anket dağıtı ımıs, eksik bırakılan ve hatalı doldurulan 47 anket, araştırma kapsamına alınmamıştır. Toplamda 361 anket değerlendirmeye alınmıştır. Anket, internet üzerinden çevrimiçi olarak anket oluşturma imkânı sunan "surveymonkey.com" internet sitesi aracılığıyla uygulanmış ve veriler 2019 sonu itibariyle toplanmaya başlamış ve 2020 yılının ilk yarısında veri toplama işlemi tamamlanmıştır. Öğrencilere kartopu örnekleme yöntemiyle, çalışanlara ise kolayda örnekleme yöntemiyle ulaşılmıştır. Öğrencilerin tamamı tek bir devlet üniversitesinden olup, çalışanlar ise hem kamu hem de özel sektörde yer almaktadır.

Tablo 2. Katılımcıların Demografik Değişkenlere Göre Dağılımı

\begin{tabular}{|l|l|c|c|}
\hline \multicolumn{2}{|l|}{ Değişkenler } & Sayı (n) & Yüzde (\%) \\
\hline \multirow{2}{*}{ Cinsiyet } & Kadın & 189 & 52,4 \\
& Erkek & 172 & 47,6 \\
\hline \multirow{2}{*}{ Kuşak } & Y Kuşağı (1980-1999) & 315 & 88,2 \\
& Z Kuşağı (2000-2018) & 42 & 11,7 \\
\hline \multirow{2}{*}{ Çalışma Durumu } & Çalışan & 56 & 15,5 \\
& Öğrenci & 305 & 84,4 \\
\hline \multirow{3}{*}{ Öğrenim Durumu } & Ön lisans & 34 & 9,4 \\
& Lisans & 282 & 78,1 \\
& Lisansüstü & 45 & 12,5 \\
\hline
\end{tabular}


Katılımcıların 189'u $(\% 52,4)$ kadın, 172'si $(\% 47,6)$ erkektir. Kuşak ayrımlarına bakıldığında 315'i $(\% 88,2)$ Y kuşağı, 42'si $(\% 11,7) Z$ kuşağıdır. Katılımcıların çalışma durumu ele alındığında, 56'sı $(\% 15,5)$ çalışan, $305^{\prime} \mathrm{i}(\% 84,4)$ ise öğrencidir. Katılımcıların öğrenim durumları incelendiğinde; 34'ünün $(\% 9,4)$ ön lisans, $282^{\prime} \operatorname{sinin}(\% 78,1)$ lisans ve $45^{\prime}$ inin $(\% 12,5)$ lisansüstü eğitime sahip oldukları görülmektedir.

\section{4. Ölçme Aracı}

Veri toplama aracı olarak anket kullanılmıştır. Anketin ilk bölümünde katılımcılara demografik bilgilerini ölçmek amacıyla cinsiyet, doğum yılı, çalışma durumu ve öğrenim durumları ile ilgili sorular sorulmuştur. Bu soruların ardından "işveren çekiciliği" ve "kariyer geleceği algısı" ile ilgili sorular yöneltilmiştir.

İşveren Çekiciliği Algısı Ölçeği: Katılımcıların işveren çekiciliği algılamalarını ölçmek için Berthon vd. (2005) tarafından geliştirilen "işveren çekiciliği ölçeği”" (EmpAt) kullanılmıştır. Ölçek, Ardıç ve Gündoğmuş (2016) tarafından Türkçeye uyarlanmış olup, yapılan geçerlilik ve güvenilirlik analizi sonucunda Cronbach's alpha değeri 0,895 olarak hesaplanmıştır. İşveren çekiciliği ölçeği sosyal değer, ekonomik değer, gelişim değeri, başvuru değeri ve fayda değeri boyutları hakkında 25 ifadeden oluşmaktadır. 5'li Likert ölçeği kullanılmış olup, katılımcılara maddeleri hiç önemli değil (1)'den çok önemli (5)'ye doğru uzanan seçenekler ile yanıtlamaları istenmiştir.

Kariyer Geleceği Algısı Ölçeği: Bireylerin olumlu kariyer geleceği algılarını ölçmek için Rottinghaus vd. (2005) tarafından tasarlanan "kariyer geleceği algısı ölçeği" kullanılmıştır. Ölçek, Kalafat (2012) tarafından Türkçeye uyarlanmış olup, yapılan geçerlilik ve güvenilirlik analizi sonucunda Cronbach's alpha değeri 0,870 olarak hesaplanmıştır. 23 maddeden oluşan ölçek, 3 alt boyuta ayrılmaktadır. Kariyer uyumluluğu alt boyutu 11 maddeden, kariyer iyimserliği alt boyutu 10 maddeden ve iş piyasasına ilişkin algılanan bilgi alt boyutu 2 maddeden oluşmaktadır. Ankette 5'li Likert ölçeği kullanılmış olup, katılımcılara soruları kesinlikle katılmıyorum (1)'dan kesinlikle katılıyorum (5)'a doğru uzanan seçenekler ile yanıtlamaları istenmiştir. 10., 11., 14., 15. ve 19. ifadeler ters kodlanmıs olup, bu maddelere verilen cevaplar ters çevrilerek puanlandırımıştır. Ölçeğe ilişkin ifadelerin toplamı kariyer geleceği algısı puanını vermektedir. Kariyer geleceği algısından alınacak en yüksek toplam puan 115 , en düşük toplam puan ise $23^{\prime}$ tür. Elde edilen puanların yüksek olması katılımcının kariyer uyumluluğu ve kariyer algısının olumlu olduğunu belirtmektedir.

\subsection{Kullanılan İstatistiksel Analizler}

Araştırmada elde edilen verilerin analizinde SPSS 22.0 istatistik programı kullanılmıştır. Ölçek ve verilerin güvenilirliğini test etmek amacıyla faktör analizi ve güvenilirlik analizi yapılmışır. Değiş̧kenler arasındaki ilişkiyi, ilişkinin yönünü, şiddetini ve anlamlıı̆ını ölçmek için korelasyon analizi kullanılmıştır. Bağımsız değişkenlerin, bağımlı değişken üzerindeki etkisini ölçmek için regresyon analizi yapılmıştır. Demografik değişkenlere göre farklılıkları anlamak için bağımsız gruplar t-testi ve Anova testi yapılmıştır.

\section{Bulgular}

Bu bölümde, araştırma değişkenleri olan kariyer geleceği algısı ve işveren çekiciliği algısına ilişkin analizlere yer verilmiştir. Ölçeklerin faktör ve güvenilirlik analizleri yapılmış, değişkenler arasındaki ilişkide korelasyon ve regresyon analizlerinin sonuçlarına değinilmiş ve demografik değişkenlerin farklılıklarına ilişkin analizlere yer verilmiştir.

\section{1. Ölçme Araçları ile ilgili Faktör ve Güvenilirlik Analizi Bulguları}

\subsubsection{Kariyer Geleceği Algısı Ölçeğine ilişkin Faktör Analizi Bulguları}

Kariyer geleceği algısı ölçeği 24 ifadeden oluşmaktadır. Yapılan faktör analizi sonucunda kariyer iyimserliği alt boyutundaki dördüncü "işle ilgili yeni görevler denemekten zevk alırım" ve sekizinci "kariyer başarılarımı kendi çabalarımla belirlerim" ifadeleri, birden fazla faktör altında yer alması nedeniyle ölçekten çıkartılmıştır. Ölçek üç faktöre ayrılmış olup, bu faktörler Rottinghaus vd. (2005) tarafından tasarlanan ve 
Kalafat (2012) tarafından Türkçeye uyarlanan çalışmalarda olduğu gibi kariyer uyumluluğu, kariyer iyimserliği ve iş piyasasına ilişkin algılanan bilgi şeklinde ifade edilmiştir.

Kariyer geleceği algısı ölçeğindeki üç faktör toplam varyansın \%52,49'unu açıklamaktadır. Kariyer geleceği algısı ölçeğine ilişkin güvenilirlik değeri 0,898'tir. Faktörlerin güvenilirlik değerleri ise; kariyer uyumluluğu için 0,891, kariyer iyimserliği için 0,856 ve iş piyasasına ilişkin algılanan bilgi için 0,695'tir. Ifadelere ilişkin faktör yükleri, açıklanan varyanslar ve güvenilirlik analizi sonuçları Tablo 3'te detaylı olarak gösterilmiştir.

Tablo 3. Kariyer Geleceği Algısı Ölçeğine ilişkin Faktör ve Güvenilirlik Analizi

\begin{tabular}{|c|c|c|c|c|}
\hline $\begin{array}{l}\text { Faktör } \\
\text { Adı }\end{array}$ & ifade & $\begin{array}{l}\text { Faktör } \\
\text { Yükü }\end{array}$ & $\begin{array}{l}\text { Açılkanan } \\
\text { Varyans }\end{array}$ & $\begin{array}{c}\text { Cronbach } \\
\alpha \\
\end{array}$ \\
\hline \multirow{11}{*}{ 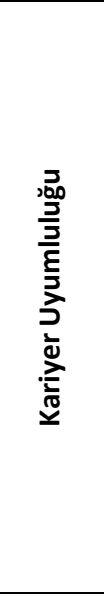 } & $\begin{array}{l}\text { Kariyer planlamadaki değişimlere uyum } \\
\text { sağlayabilirim. }\end{array}$ & 0,721 & \multirow{11}{*}{31,26} & \multirow{11}{*}{0,891} \\
\hline & İş dünyasındaki değişime uyum sağlayabilirim. & 0,721 & & \\
\hline & $\begin{array}{l}\text { Kariyerimde oluşabilecek engellerin üstesinden } \\
\text { gelebilirim. }\end{array}$ & 0,713 & & \\
\hline & Kariyerimin kontrolü nadiren benim elimdedir. & 0,697 & & \\
\hline & Yeni iş ortamına uyum sağlama konusunda iyiyim. & 0,683 & & \\
\hline & $\begin{array}{l}\text { Kariyer planım iyi gitmediğinde kendimi toparlama } \\
\text { eğilimindeyimdir. }\end{array}$ & 0,670 & & \\
\hline & $\begin{array}{l}\text { Çevremdekiler kariyerimdeki değişimlere uyum } \\
\text { sağlayabileceğimi söylerler. }\end{array}$ & 0,668 & & \\
\hline & Kariyer başarımı kontrol edemem. & 0,662 & & \\
\hline & Kariyer başarılarımı kendi çabalarımla belirlerim. & 0,657 & & \\
\hline & İşte değişen taleplere kolayca uyum sağlarım. & 0,640 & & \\
\hline & İşle ilgili yeni görevler denemekten zevk alırım. & 0,640 & & \\
\hline \multirow{8}{*}{ 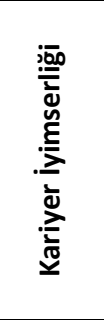 } & Kariyerimi düşünmek ilham veriyor. & 0,785 & \multirow{8}{*}{14,05} & \multirow{8}{*}{0,862} \\
\hline & Kariyerim hakkında düşününce heyecanlanıyorum. & 0,713 & & \\
\hline & Kariyerimi düşünmek bende hayal kırıklığı yaratıyor. & 0,702 & & \\
\hline & Kariyer hayallerimi sürdürmek konusunda istekliyim. & 0,691 & & \\
\hline & Kariyerimi planlamak benim için doğal bir faaliyettir. & 0,691 & & \\
\hline & Kariyerimle ilgili doğru kararlar verdiğimden eminim. & 0,687 & & \\
\hline & Gelecekteki kariyer başarımdan eminim. & 0,657 & & \\
\hline & İş ile ilgili beklentilerimin farkındayım. & 0,604 & & \\
\hline \multirow{2}{*}{ 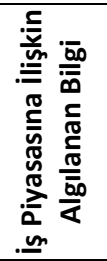 } & Gelecekteki istihdam eğilimlerini öngörmek kolaydır. & 0,835 & \multirow{2}{*}{7,18} & \multirow{2}{*}{0,695} \\
\hline & İş piyasasının eğilimlerini anlama konusunda iyiyim. & 0,827 & & \\
\hline
\end{tabular}

\subsection{2. İ̧sveren Çekiciliği Algısı Ölçeğine Ilişsin Faktör Analizi Bulguları}

İşveren çekiciliği algısı ölçeği 25 maddeden oluşmaktadır. Faktör analizi sonucunda uygulama değeri alt boyutundaki dördüncü "çalıştığım işletmede kabul görmem ve aidiyet hissetmem" ve beşinci "çalıştığım işletmenin müşteri odaklı olması" ifadeleri, birden fazla faktör altında yer aldığından ölçekten çıkartılmıştır. Analiz sonucunda ölçek 23 madde ve 5 faktörden oluşmuş olup, faktörler Berthon vd. (2005) tarafından tasarlanan "işveren çekiciliği ölçeği" ile benzerlik göstermektedir.

Analiz sonucunda, işveren çekiciliği algısı ölçeğinde oluşan faktörler toplam varyansın \%61,33 açıklamaktadır. Ölçeğin güvenilirlik değerine ilişkin KMO katsayısı 0,838'dir. Faktörlerin güvenilirlik değerleri ise; kariyer uyumluluğu için 0,891, kariyer iyimserliği için 0,856 ve iş piyasasına ilişkin algılanan bilgi için 0,695 'tir. Maddelere ilişkin faktör yükleri, açıklanan varyanslar ve güvenilirlik analizi sonuçları Tablo 4 'te detaylı olarak gösterilmiştir. 
Tablo 4. İşveren Çekiciliği Algısı Ölçeğine İlişkin Faktör ve Güvenilirlik Analizi

\begin{tabular}{|c|c|c|c|c|}
\hline $\begin{array}{l}\text { Faktör } \\
\text { Adı }\end{array}$ & ifade & $\begin{array}{l}\text { Faktör } \\
\text { Yükü }\end{array}$ & $\begin{array}{l}\text { Açılklanan } \\
\text { Varyans }\end{array}$ & $\begin{array}{c}\text { Cronbach } \\
\alpha\end{array}$ \\
\hline \multirow{5}{*}{ 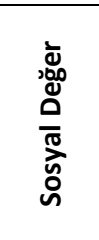 } & İş arkadaşlarımla iyi ilişkilere sahip olmam & 0,845 & \multirow{5}{*}{24,49} & \multirow{5}{*}{0,865} \\
\hline & $\begin{array}{l}\text { Destekleyici ve teşvik edici iş arkadaşlarına sahip } \\
\text { olmam }\end{array}$ & 0,809 & & \\
\hline & Mutlu bir çalışma ortamımın olması & 0,780 & & \\
\hline & Üstlerle iyi ilişkilere sahip olmam & 0,742 & & \\
\hline & Eğlenceli bir çalışma ortamımın olması & 0,731 & & \\
\hline \multirow{5}{*}{ 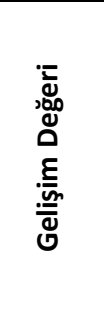 } & $\begin{array}{l}\text { İşletmede çalışmam sonucunda kendime güvenimin } \\
\text { artması }\end{array}$ & 0,817 & \multirow{5}{*}{12,21} & \multirow{5}{*}{0,826} \\
\hline & $\begin{array}{l}\text { Çalıştığım işletmenin gelecekteki kariyer hedeflerim } \\
\text { için iyi bir basamak olması }\end{array}$ & 0,812 & & \\
\hline & $\begin{array}{l}\text { Çalıştığım işletmenin bana kariyerimi geliştirecek } \\
\text { deneyimler kazandırması }\end{array}$ & 0,772 & & \\
\hline & Yönetim tarafından tanınmam ve takdir edilmem & 0,733 & & \\
\hline & Bilinen, tanınan bir işletmede çalışıyor olmam & 0,651 & & \\
\hline \multirow{5}{*}{ 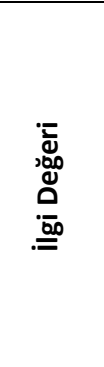 } & $\begin{array}{l}\text { Çalıştığım işletmenin yenilikçi ürün ve hizmetler } \\
\text { sunması }\end{array}$ & 0,806 & \multirow{5}{*}{9,70} & \multirow{5}{*}{0,824} \\
\hline & $\begin{array}{l}\text { Çalıştı̆̆ım işletmenin hem yaratıcılığa değer vermesi } \\
\text { hem de bundan faydalanması }\end{array}$ & 0,786 & & \\
\hline & $\begin{array}{l}\text { Çalıştı̆̆ım işletmede yüksek kalitede ürün ve } \\
\text { hizmetler sunulması }\end{array}$ & 0,753 & & \\
\hline & $\begin{array}{l}\text { İşverenimin yeni iş uygulamalarına açık ve ileri } \\
\text { görüşlü olması }\end{array}$ & 0,665 & & \\
\hline & Heyecan verici bir çalışma ortamımın olması & 0,652 & & \\
\hline \multirow{5}{*}{ 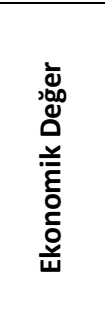 } & $\begin{array}{l}\text { Cazip ve kapsamlı ödeme paketi (yemek ücreti, } \\
\text { bireysel emeklilik, prim vs.) sunulması }\end{array}$ & 0,765 & \multirow{5}{*}{9,28} & \multirow{5}{*}{0,777} \\
\hline & İşletme içerisinde terfi fırsatlarının iyi olması & 0,761 & & \\
\hline & Çalıştığım işletmede iş güvencemin olması & 0,759 & & \\
\hline & $\begin{array}{l}\text { Çalıştığım işletmenin ortalamanın üzerinde ücret } \\
\text { sunması }\end{array}$ & 0,721 & & \\
\hline & $\begin{array}{l}\text { Çalıştığım işletmede departmanlar arası deneyim } \\
\text { elde etme fırsatımın olması }\end{array}$ & 0,633 & & \\
\hline \multirow{3}{*}{ 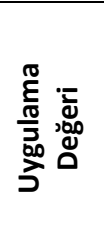 } & $\begin{array}{l}\text { Çalıştığım işletmenin sosyal sorumluluk sahibi bir } \\
\text { kurum olması }\end{array}$ & 0,750 & \multirow{3}{*}{5,64} & \multirow{3}{*}{0,693} \\
\hline & $\begin{array}{l}\text { Çalıştığım işletmede öğrendiklerimi başkalarına } \\
\text { öğretme / aktarma fırsatımın olması }\end{array}$ & 0,747 & & \\
\hline & $\begin{array}{l}\text { Çalıştığım işletmede öğrendiklerimi uygulama fırsatı } \\
\text { verilmesi }\end{array}$ & 0,713 & & \\
\hline
\end{tabular}

\section{2. Ölçme Araçlarına İlişkin Betimsel İstatistikler ve Değişkenler Arası Korelasyon}

Kariyer geleceği algısı ve işveren çekiciliği algısı boyutlarına ilişkin betimsel istatistikler Tablo 6 'da yer almaktadır. Kariyer geleceği algısına ait ortalama değer 3,89 (std. sapma: 0,44) olarak hesaplanmıştır. Katılımcıların "katılıyorum" ifadesine yakın cevaplar verdikleri görülmektedir. Kariyer geleceği algısının alt boyutlarına bakıldığında; kariyer uyumluluğuna ilişkin ortalama değerin 3,92 (std. sapma: 0,54) ve kariyer iyimserliğine ilişkin ortalama değerin ise 3,97 (std. sapma: 0,58) olduğu görülmektedir. Katılımcıların kariyer uyumluluğu ve kariyer iyimserliğine ilişkin "katılıyorum" ifadesine yakın cevaplar verdikleri görülmektedir. İ̧̧ piyasasına ilişkin algılanan bilgi boyutunun ortalama değerinin 3,33 (std. sapma: 0,83 ) olduğu ve katılımcıların "kararsızım" ifadesine yakın cevaplar verdikleri görülmektedir.

İşveren çekiciliği boyutlarına bakıldığında; sosyal değer ortalamasının 4,21 (std. sapma: 0,69), ekonomik değer ortalamasının 4,21 (std. sapma: 0,60), gelişim değeri ortalamasının 4,11 (Std. Sapma: 0,69), fayda değeri ortalamasının 4,24 (std. sapma: 0,58 ) ve uygulama değeri ortalamasının 4,35 (std. sapma: 0,61 ) 
olduğu anlaşılmaktadır. Katılımcıların işveren çekiciliği boyutlarına "önemli" seçeneğine yakın cevaplar verdiği görülmektedir (Tablo 5).

Tablo 5. Ölçme Araçlarına İlişkin Betimsel İstatistikler Tablosu

\begin{tabular}{|c|c|c|c|}
\hline Değişkenler ve Alt Boyutları & $\mathbf{n}$ & Ortalama & Standart Sapma \\
\hline Kariyer Geleceği Algısı & 361 & 3,89 & 0,44 \\
\hline Kariyer Uyumluluğu & 361 & 3,92 & 0,54 \\
\hline Kariyer İyimserliği & 361 & 3,97 & 0,58 \\
\hline İş Piyasasına ilişkin Algılanan Bilgi & 361 & 3,33 & 0,83 \\
\hline \multicolumn{4}{|l|}{ İşveren Çekiciliği Algısı } \\
\hline Sosyal Değer & 361 & 4,21 & 0,69 \\
\hline Ekonomik Değer & 361 & 4,21 & 0,60 \\
\hline Gelişim Değeri & 361 & 4,11 & 0,69 \\
\hline İlgi Değeri & 361 & 4,24 & 0,58 \\
\hline Uygulama Değeri & 361 & 4,35 & 0,61 \\
\hline
\end{tabular}

Kariyer geleceği algısı ile işveren çekiciliği algısı boyutları arasında doğrusal bir ilişki olup olmadığının tespit edilebilmek ve ilişki olması durumunda bu ilişkinin yönü ve şiddetini belirlemek için korelasyon analizi yapılmıştır. Değişkenler arasındaki ilişki, korelasyon katsayısının 0,30'dan küçük olması durumunda zayıf, 0,31 ile 0,70 arasında olması durumunda orta ve $0,71^{\prime}$ den büyük olması durumunda güçlü olarak yorumlanmaktadır (Çokluk vd., 2016, 35). Veriler normal dağılıma sahip olmadığından Spearman korelasyon analizi kullanılmıştır. Korelasyon değerleri Tablo 6'da gösterilmektedir.

Tablo 6. Değişkenler Arası Korelasyon Değerleri

\begin{tabular}{|l|l|l|l|l|l|l|l|l|l|l|}
\hline & 1 & 2 & 3 & 4 & 5 & 6 & 7 & 8 & 9 & 10 \\
\hline $\begin{array}{l}\text { Kariyer Geleceği } \\
\text { Algısı }\end{array}$ & 1,00 & & & & & & & & & \\
\hline $\begin{array}{l}\text { Kariyer } \\
\text { Uyumluluğu }\end{array}$ & $0,81^{* *}$ & 1,00 & & & & & & & & \\
\hline $\begin{array}{l}\text { Kariyer } \\
\text { İyimserliği }\end{array}$ & $0,78^{* *}$ & $0,37^{* *}$ & 1,00 & & & & & & & \\
\hline Algılanan Bilgi & $0,40^{* *}$ & $0,19^{* *}$ & $0,21^{* *}$ & 1,00 & & & & & & \\
\hline $\begin{array}{l}\text { İşveren Çekiciliği } \\
\text { Algısı }\end{array}$ & $0,28^{* *}$ & $0,30^{* *}$ & $0,16^{* *}$ & 0,06 & 1,00 & & & & & \\
\hline Sosyal Değer & $0,27^{* *}$ & $0,33^{* *}$ & $0,12^{*}$ & 0,03 & $0,69^{* *}$ & 1,00 & & & & \\
\hline Ekonomik Değer & $-0,38^{* *}$ & $-0,24^{* *}$ & $-0,45^{* *}$ & $-0,09$ & $0,37^{* *}$ & 0,09 & 1,00 & & & \\
\hline Gelişim Değeri & $0,40^{* *}$ & $0,32^{* *}$ & $0,35^{* *}$ & $0,10^{*}$ & $0,66^{* *}$ & $0,31^{* *}$ & 0,03 & 1,00 & & \\
\hline İlgi Değeri & $0,34^{* *}$ & $0,31^{* *}$ & $0,25^{* *}$ & $0,12^{*}$ & $0,67^{* *}$ & $0,39^{* *}$ & 0,05 & $0,31^{* *}$ & 1,00 & \\
\hline $\begin{array}{l}\text { Uygulama } \\
\text { Değeri }\end{array}$ & $0,21^{* *}$ & $0,12^{*}$ & $0,20^{* *}$ & $0,11^{*}$ & $0,61^{* *}$ & $0,26^{* *}$ & $0,18^{* *}$ & $0,36^{* *}$ & $0,45^{* *}$ & 1,00 \\
\hline
\end{tabular}

** 0,01 önem seviyesinde korelasyon vardır.

* 0,05 önem seviyesinde korelasyon vardır.

Kariyer geleceği algısının, işveren çekiciliği algısı boyutlarıyla ilişkisi incelendiğinde; gelişim değeri ile orta derecede $(\% 40,8)$ ve pozitif yönlü bir ilişkisi olduğu görülmektedir. Kariyer geleceği algısının fayda değeri $(\% 34,9)$, sosyal değer $(\% 27)$ ve uygulama değeri $(\% 21,2)$ ile zayıf derecede ve anlamlı bir ilişkisi varken, ekonomik değer ile orta derecede $(-\% 38,7)$ negatif yönde anlamlı bir ilişkisinin bulunduğu görülmektedir. Kariyer geleceği algısı boyutlarından kariyer uyumluluğunun, işveren çekiciliği boyutlarından sosyal değer $(\% 33,4)$, gelişim değeri $(\% 32,8)$, fayda değeri $(\% 31,4)$ ve uygulama değeri $(\% 12,7)$ ile zayıf derecede ve anlamlı $(p<0,05)$ bir ilişkisi varken, ekonomik değer ile zayıf derecede $(-\% 24,5)$ negatif yönde anlamlı $(p<0,05)$ bir ilişkisinin bulunduğu görülmektedir. Kariyer geleceği algısı boyutlarından kariyer iyimserliğinin, işveren çekiciliği boyutlarından gelişim değeri $(\% 35,8)$, fayda değeri $(\% 25,7)$, uygulama değeri $(\% 20,1)$ ve sosyal değer 
$(\% 12,8)$ ile zayıf derecede ve anlamlı $(p<0,05)$ bir ilişkisi varken, ekonomik değer ile orta derecede $(-\% 45,7)$ negatif yönde anlamlı $(p<0,05)$ bir ilişkisinin bulunduğu görülmektedir. Kariyer geleceği algısı boyutlarından iş piyasasına ilişkin algılanan bilgi, işveren çekiciliği boyutlarından gelişim değeri $(\% 12,7)$ ve uygulama değeri $(\% 11,6)$ zayıf derecede ve anlamlı $(p<0,05)$ bir ilişkisi varken, sosyal değer, ekonomik değer ve gelişim değeri boyutlarıyla anlamlı bir ilişkisi bulunmamaktadır $(p>0,05)$.

\section{Analizleri}

4.3. Kariyer Geleceği Algısının İşveren Çekiciliği Algısı Boyutlarına Etkisine iliş̧kin Regresyon

Araştırmada katılımcıların kariyer geleceği algılarının işveren çekiciliği algısını etkilediği öne sürülmüştür. Araştırma hipotezini test etmek amacıyla bağımsız değişken olan kariyer geleceği algısının, bağımlı değişken olan işveren çekiciliği üzerindeki etkisini incelemek amacıyla regresyon analizleri yapılmıştır. Regresyon analizinin yapılabilmesi için ilgili varsayımların testi yapılmıştır. Buna göre; değişkenler arasında doğrusal ilişki vardır, veri serilerinde önemli uç değerler yoktur, varyansların eşitliği varsayımı söz konusudur, kalıntı değişken yaklaşık olarak normal dağılmıştır ve çoklu regresyon analizinde de bağımsız değişkenler arasında önemli bir çoklu doğrusalık yoktur.

Kariyer geleceği algısının işveren çekiciliği algısına olan etkisine ilişkin yapılan regresyon analizi sonucunda, kariyer geleceği algısının, işveren çekiciliği algısına etkisinin istatistiksel olarak anlamlı olduğu görülmektedir $(p=0,00)$. Kariyer geleceği algısı, işveren çekiciliği algısını $\% 95$ güven aralığında $(p<0,05, \beta$ : $0,295)$ pozitif yönlü olarak etkilemektedir.

Tablo 7. Kariyer Geleceği Algısının İşveren Çekiciliği Algısına Etkisine İlişkin Regresyon Analizi

\begin{tabular}{|ll|c|c|c|}
\hline \multicolumn{4}{|l|}{ Bağımlı Değişken: İşveren Çekiciliği Algısı } \\
\hline Bağımsız Değişken & Beta & t & p \\
\hline Kariyer Geleceği Algısı & & 0,295 & 5,81 & 0,00 \\
\hline$R=0,295$ & $R^{2}=0,087 \quad F=33,761 \quad p=0,00$ \\
\hline
\end{tabular}

Bununla birlikte kariyer geleceği algısının ve kariyer geleceği algısı boyutlarının işveren çekiciliği boyutları üzerine yapılan regresyon analizi sonucunda kariyer geleceği algısının, işveren çekiciliği boyutlarından sosyal değere etkisinin istatistiksel olarak anlamlı olduğu görülmektedir $(p=0,00)$. Kariyer geleceği algısı sosyal değer boyutunu \%95 güven aralığında $(p<0,05, \beta: 0,349)$ pozitif yönlü olarak etkilemekte olup, sosyal değerdeki değişimi \%12,2 oranında açıklamaktadır.

Tablo 8. Kariyer Geleceği Algısının ve Boyutlarının Sosyal Değer Boyutuna Etkisine Illişkin Regresyon Analizi

\begin{tabular}{|l|c|c|c|}
\hline \multicolumn{4}{|l|}{ Bağımlı Değişken: Sosyal Değer Boyutu } \\
\hline Bağımsız Değişken & Beta & t & p \\
\hline Kariyer Geleceği AlgıSı & 0,349 & 7,055 & 0,00 \\
\hline$R=0,349 \quad \mathrm{R}^{2}=0,122 \quad \mathrm{~F}=49,768$ & $\mathrm{p}=0,00$ \\
\hline Bağımsız Değişkenler & Beta & $\mathbf{t}$ & $\mathbf{p}$ \\
\hline Kariyer Uyumluluğu & 0,422 & 8,120 & 0,00 \\
Kariyer İyimserliği & 0,023 & 0,437 & 0,66 \\
İş Piyasasına Ilişkin Algılanan Bilgi & $-0,062$ & $-1,244$ & 0,21 \\
\hline $\mathrm{R}=0,420 \quad \mathrm{R}^{2}=0,177 \quad \mathrm{~F}=25,515$ & $\mathrm{p}=0,00$ \\
\hline
\end{tabular}

Kariyer geleceği algısı boyutlarından kariyer uyumluluğunun, sosyal değeri \%95 güven aralığında anlamlı ve pozitif yönde etkilediği görülmektedir $(p<0,05, \beta: 0,422)$. Kariyer uyumluluğu, sosyal değerdeki değişimi \%17,7 oranında açıklamaktadır. Kariyer iyimserliği $(p=0,66)$ ve iş piyasasına ilişkin algılanan bilgi 
$(p=0,21)$ boyutlarının, sosyal değeri istatistiksel açıdan anlamlı bir şekilde etkilemediği anlaşılmıştır $(p>0,05)$ (Tablo 8).

Yapılan regresyon analizi sonucunda kariyer geleceği algısının, işveren çekiciliği algısı boyutlarından ekonomik değere etkisinin istatistiksel olarak anlamlı olduğu görülmektedir $(p=0,00)$. Kariyer geleceği algısı ekonomik değer boyutunu \%95 güven aralığında $(p<0,05, \beta:-0,425)$ negatif yönlü olarak etkilemekte olup, ekonomik değerdeki değişimi \%18 oranında açıklamaktadır.

Tablo 9. Kariyer Geleceği Algısının ve Boyutlarının Ekonomik Değer Boyutuna Etkisine İlişkin Regresyon Analizi

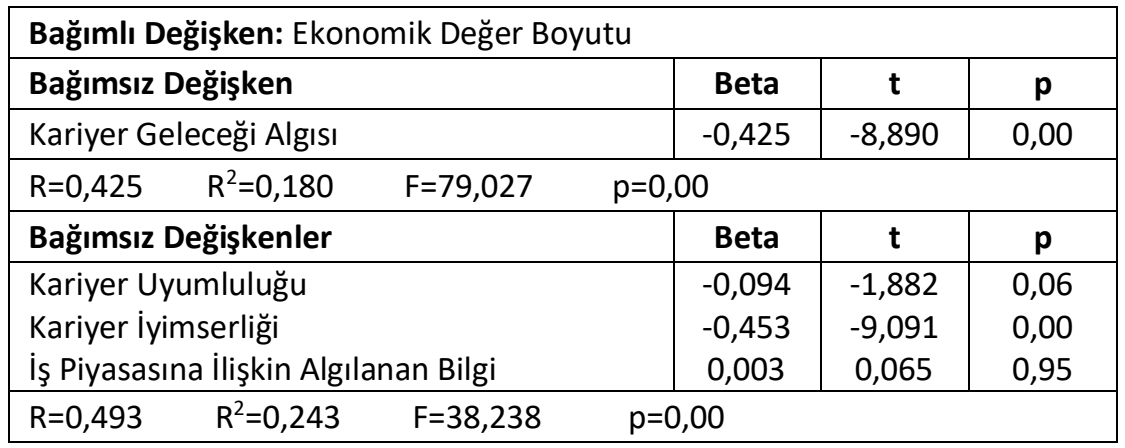

Kariyer geleceği algısı boyutlarından kariyer iyimserliğinin, ekonomik değeri \%95 güven aralığında anlamlı ve pozitif yönde etkilediği görülmektedir ( $p<0,05, \beta:-0,453)$. Kariyer iyimserliği, ekonomik değerdeki değişimi \%24,3 oranında açıklamaktadır. Kariyer uyumluluğu $(p=0,06)$ ve iş piyasasına ilişkin algılanan bilgi $(p=0,95)$ boyutlarının, ekonomik değeri istatistiksel açıdan anlamlı bir şekilde etkilemediği anlaşılmıştır ( $p>0,05$ ) (Tablo 9).

Yapılan regresyon analizi sonucunda kariyer geleceği algısının, işveren çekiciliği boyutlarından gelişim değerine etkisinin istatistiksel olarak anlamlı olduğu görülmektedir $(p=0,00)$. Kariyer geleceği algısı gelişim değeri boyutunu \%95 güven aralığında $(p<0,05, \beta: 0,455)$ pozitif yönlü olarak etkilemekte olup, gelişim değerindeki değişimi \%20,7 oranında açıklamaktadır.

Tablo 10. Kariyer Geleceği Algısının ve Boyutlarııın Gelişim Değeri Boyutuna Etkisine Illişkin Regresyon Analizi

\begin{tabular}{|l|c|c|c|}
\hline \multicolumn{5}{|l|}{ Bağımlı Değişken: Gelişim Değeri Boyutu } \\
\hline Bağımsız Değişken & Beta & t & p \\
\hline Kariyer Geleceği Algısı & 0,455 & 9,675 & 0,00 \\
\hline$R=0,455 \quad R^{2}=0,207 \quad F=93,609$ & $p=0,00$ \\
\hline Bağımsız Değişkenler & Beta & t & p \\
\hline Kariyer Uyumluluğu & 0,312 & 6,162 & 0,00 \\
Kariyer İyimserliği & 0,259 & 5,106 & 0,00 \\
İş Piyasasına İlişkin Algılanan Bilgi & $-0,020$ & $-0,412$ & 0,68 \\
\hline$R=0,465 \quad R^{2}=0,217 \quad F=32,890$ & $p=0,00$ \\
\hline
\end{tabular}

Kariyer geleceği algısı boyutlarından kariyer uyumluluğu $(p<0,05, \beta: 0,312)$ ve kariyer iyimserliğinin $(p<0,05, \beta: 0,259)$, gelişim değerini \%95 güven aralığında anlamlı ve pozitif yönde etkilediği görülmektedir. Kariyer uyumluluğu ve kariyer iyimserliği, gelişim değerindeki değişimi \%21,7 oranında açıklamaktadır. İş piyasasına ilişkin algılanan bilgi boyutunun, gelişim değerini istatistiksel açıdan anlamlı bir şekilde etkilemediği anlaşıımıştır ( $p>0,05)$ (Tablo 10). 
Yapılan regresyon analizi sonucunda kariyer geleceği algısının, işveren çekiciliği boyutlarından fayda değerine etkisinin istatistiksel olarak anlamlı olduğu görülmektedir $(p=0,00)$. Kariyer geleceği algısı fayda değeri boyutunu \%95 güven aralığında $(p<0,05, \beta$ : 0,347) pozitif yönlü olarak etkilemekte olup, fayda değerindeki değişimi \%12,1 oranında açıklamaktadır.

Tablo 11. Kariyer Geleceği Algısının ve Boyutlarının Fayda Değeri Boyutuna Etkisine Illişkin Regresyon Analizi

\begin{tabular}{|c|c|c|c|c|}
\hline \multicolumn{5}{|c|}{ Bağımlı Değişken: Fayda Değeri Boyutu } \\
\hline \multicolumn{2}{|c|}{ Bağımsız Değişken } & Beta & $\mathbf{t}$ & p \\
\hline \multicolumn{2}{|c|}{ Kariyer Geleceği Algısı } & 0,347 & 7,015 & 0,00 \\
\hline$R=0,347$ & $R^{2}=0,121$ & & & \\
\hline \multicolumn{2}{|c|}{ Bağımsız Değişkenler } & Beta & $\mathrm{t}$ & $\mathbf{p}$ \\
\hline & 0,253 & 4,723 & 0,00 \\
\hline \multirow{2}{*}{\multicolumn{2}{|c|}{$\begin{array}{l}\text { Kariyer İyimserliği } \\
\text { İş Piyasasına İlişkin Algılanan Bilgi }\end{array}$}} & 0,149 & 2,778 & 0,01 \\
\hline & & 0,040 & 0,784 & 0,43 \\
\hline
\end{tabular}

Kariyer geleceği algısı boyutlarından kariyer uyumluluğu $(p<0,05, \beta: 0,253)$ ve kariyer iyimserliğinin $(p<0,05, \beta: 0,149)$, fayda değerini \%95 güven aralığında anlamlı ve pozitif yönde etkilediği görülmektedir. Kariyer uyumluluğu ve kariyer iyimserliği, fayda değerindeki değişimi \%12,2 oranında açıklamaktadır. İş piyasasına ilişkin algılanan bilgi boyutunun, fayda değerini istatistiksel açıdan anlamlı bir şekilde etkilemediği anlaşılmıştır ( $p>0,05)$ (Tablo 11).

Yapılan regresyon analizi sonucunda kariyer geleceği algısının, işveren çekiciliği algısı boyutlarından uygulama değerine etkisinin istatistiksel olarak anlamlı olduğu görülmektedir $(p=0,00)$. Kariyer geleceği algısı uygulama değeri boyutunu \%95 güven aralığında $(p<0,05, \beta: 0,169)$ pozitif yönlü olarak etkilemekte olup, fayda değerindeki değişimi \%2,8 oranında açıklamaktadır.

Tablo 12. Kariyer Geleceği Algısının ve Boyutlarının Uygulama Değeri Boyutuna Etkisine İlişkin Regresyon Analizi

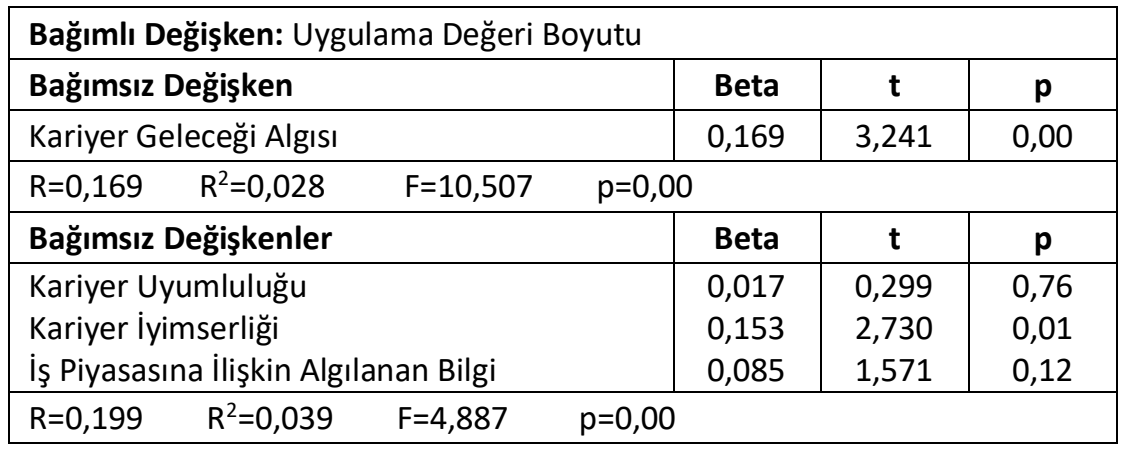

Kariyer geleceği algısı boyutlarından kariyer iyimserliğinin, uygulama değerini \%95 güven aralı̆̆ında anlamlı ve pozitif yönde etkilediği görülmektedir $(p<0,05, \beta: 153)$. Kariyer iyimserliği, uygulama değerindeki değişimi \%3,9 oranında açıklamaktadır. Kariyer uyumluluğu $(p=0,76)$ ve iş piyasasına ilişkin algılanan bilgi $(p=0,12)$ boyutlarının, uygulama değerini istatistiksel açıdan anlamlı bir şekilde etkilemediği anlaşılmıştır $(p>0,05)$ (Tablo 12). 


\subsection{Demografik Değişkenler Açısından Farklılıklar}

\subsubsection{Cinsiyete Göre Kariyer Geleceği Algısı ve İşveren Çekiciliği Algısına İlişkin Farklılıklar}

Cinsiyete göre kariyer geleceği algısı açısından istatistiksel olarak anlamlı bir farklılık olduğu anlaşılmıştır $(p=0,02)$. Kariyer geleceği algısının alt boyutları incelendiğinde, kariyer uyumluluğu açısından cinsiyete göre anlamlı bir farklılık olduğu görülmektedir $(p=0,01)$. Kariyer iyimserliği ve iş piyasasına ilişkin algılanan bilgi boyutlarının cinsiyete göre anlamlı bir farklılık göstermediği anlaşılmıştır $(p>0,05)$.

Tablo 13. Cinsiyete Göre Kariyer Geleceği Algısı ve İşveren Çekiciliği Algısı Açısından t-Testi Sonuçları

\begin{tabular}{|c|c|c|c|c|c|c|}
\hline & & & $\mathbf{n}$ & Ort. & SS & $\mathbf{p}$ \\
\hline \multirow{8}{*}{ 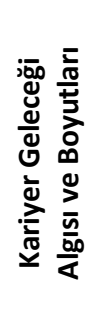 } & \multirow{2}{*}{ Kariyer Geleceği Algısı } & Kadın & 189 & 3,93 & 0,43 & \multirow{2}{*}{0,02} \\
\hline & & Erkek & 172 & 3,83 & 0,45 & \\
\hline & \multirow{2}{*}{ Kariyer Uyumluluğu } & Kadın & 189 & 4,01 & 0,45 & \multirow{2}{*}{0,01} \\
\hline & & Erkek & 172 & 3,82 & 0,60 & \\
\hline & \multirow{2}{*}{ Kariyer İyimserliği } & Kadın & 189 & 3,99 & 0,60 & \multirow{2}{*}{0,59} \\
\hline & & Erkek & 172 & 3,95 & 0,56 & \\
\hline & \multirow{2}{*}{ Algılanan Bilgi } & Kadın & 189 & 3,33 & 0,85 & \multirow{2}{*}{0,93} \\
\hline & & Erkek & 172 & 3,32 & 0,81 & \\
\hline \multirow{12}{*}{ 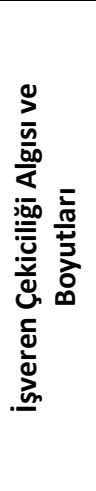 } & \multirow{2}{*}{ İşveren Çekiciliği Algısı } & Kadın & 189 & 4,29 & 0,36 & \multirow{2}{*}{0,00} \\
\hline & & Erkek & 172 & 4,12 & 0,39 & \\
\hline & \multirow{2}{*}{ Sosyal Değer } & Kadın & 189 & 4,30 & 0,66 & \multirow{2}{*}{0,00} \\
\hline & & Erkek & 172 & 4,10 & 0,70 & \\
\hline & \multirow{2}{*}{ Ekonomik Değer } & Kadın & 189 & 4,23 & 0,62 & \multirow{2}{*}{0,39} \\
\hline & & Erkek & 172 & 4,17 & 0,56 & \\
\hline & \multirow{2}{*}{ Gelişim Değeri } & Kadın & 189 & 4,21 & 0,63 & \multirow{2}{*}{0,22} \\
\hline & & Erkek & 172 & 4,00 & 0,74 & \\
\hline & \multirow{2}{*}{ Fayda Değeri } & Kadın & 189 & 4,32 & 0,57 & \multirow{2}{*}{0,77} \\
\hline & & Erkek & 172 & 4,13 & 0,58 & \\
\hline & \multirow{2}{*}{ Uygulama Değeri } & Kadın & 189 & 4,45 & 0,58 & \multirow{2}{*}{0,04} \\
\hline & & Erkek & 172 & 4,24 & 0,63 & \\
\hline
\end{tabular}

Cinsiyete göre işveren çekiciliği algısı açısından anlamlı $(p=0,00)$ bir farklılık olduğu anlaşılmıştır. Cinsiyete göre farklılıklara işveren çekiciliği boyutları açısından bakıldığında, sosyal değer $(p=0,00)$ ve uygulama değeri $(p=0,04)$ açısından cinsiyete göre anlamlı bir farklılık olduğu gözükmektedir. Ekonomik değer, gelişim değeri ve uygulama değerinin cinsiyete göre anlamlı bir farklılık olmadığı anlaşılmıştır $(p>0,05)$ (Tablo 13).

\subsubsection{Kuşaklara Göre Kariyer Geleceği Algısı ve İşveren Çekiciliği Algısına İlişkin Farklııklar}

Kuşaklara göre kariyer geleceği algısına ilişkin yapılan analizler sonucunda, Z kuşağındaki bireylerin kariyer geleceği algısı boyutlarına ilişkin ortalamalarının, $Y$ kuşağındaki bireylere göre daha yüksek olmasına rağmen bu farklılığın istatistiksel olarak anlamlı olmadığı anlaşılmıştır ( $p>0,05)$. 
Kariyer Geleceği Algılamalarının İşveren Çekiciliği Algısına Etkisi

Tablo 14. Kuşaklara Göre Kariyer Geleceği Algısı ve İşveren Çekiciliği Algısı Açısından t-Testi Sonuçları

\begin{tabular}{|c|c|c|c|c|c|c|}
\hline & & & $\mathbf{n}$ & Ort. & ss & $\mathbf{p}$ \\
\hline \multirow{8}{*}{ 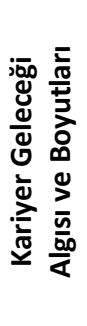 } & \multirow{2}{*}{ Kariyer Geleceği Algısı } & Z Kuşağı & 42 & 3,92 & 0,48 & \multirow{2}{*}{0,56} \\
\hline & & Y Kuşağı & 315 & 3,88 & 0,44 & \\
\hline & \multirow{2}{*}{ Kariyer Uyumluluğu } & Z Kuşağı & 42 & 3,93 & 0,55 & \multirow{2}{*}{0,92} \\
\hline & & Y Kuşağı & 315 & 3,92 & 0,54 & \\
\hline & \multirow{2}{*}{ Kariyer İyimserliği } & Z Kuşağı & 42 & 4,02 & 0,59 & \multirow{2}{*}{0,54} \\
\hline & & Y Kuşağı & 315 & 3,96 & 0,58 & \\
\hline & \multirow{2}{*}{ Algılanan Bilgi } & Z Kuşağı & 42 & 3,46 & 0,72 & \multirow{2}{*}{0,24} \\
\hline & & Y Kuşağı & 315 & 3,30 & 0,85 & \\
\hline \multirow{12}{*}{ 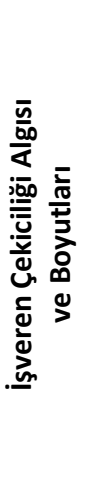 } & \multirow{2}{*}{ İşveren Çekiciliği Algısı } & Z Kuşağı & 42 & 4,09 & 0,31 & \multirow{2}{*}{0,04} \\
\hline & & Y Kuşağı & 315 & 4,23 & 0,39 & \\
\hline & \multirow{2}{*}{ Sosyal Değer } & Z Kuşağı & 42 & 4,10 & 0,54 & \multirow{2}{*}{0,29} \\
\hline & & Y Kuşağı & 315 & 4,22 & 0,71 & \\
\hline & \multirow{2}{*}{ Ekonomik Değer } & Z Kuşağı & 42 & 4,06 & 0,62 & \multirow{2}{*}{0,11} \\
\hline & & Y Kuşağı & 315 & 4,22 & 0,60 & \\
\hline & \multirow{2}{*}{ Gelişim Değeri } & Z Kuşağı & 42 & 3,91 & 0,76 & \multirow{2}{*}{0,05} \\
\hline & & Y Kuşağı & 315 & 4,14 & 0,68 & \\
\hline & \multirow{2}{*}{ Fayda Değeri } & Z Kuşağı & 42 & 4,17 & 0,56 & \multirow{2}{*}{0,45} \\
\hline & & Y Kuşağı & 315 & 4,24 & 0,59 & \\
\hline & \multirow{2}{*}{ Uygulama Değeri } & Z Kuşağı & 42 & 4,31 & 0,60 & \multirow{2}{*}{0,59} \\
\hline & & Y Kuşağı & 315 & 4,36 & 0,61 & \\
\hline
\end{tabular}

Kuşaklara göre işveren çekiciliği algısı açısından anlamlı $(p=0,04)$ bir farklılık olduğu anlaşılmıştır. Kuşaklara göre farklılıklara işveren çekiciliği boyutları açısından bakıldığında, gelişim değeri açısından anlamlı $(p=0,05)$ bir farklılık olduğu görülmektedir. Sosyal değer, ekonomik değer, fayda değeri ve uygulama değeri açısından kuşaklara göre anlamlı bir farklıık bulunmadığı anlaşılmıştır ( $p>0,05)$ (Tablo 13). Diğer kuşaklarda yer alan katılımcılar (X kuşağından 3, sessiz kuşaktan 1 katılımcı) sayılarının az olması nedeniyle yapılan analizde değerlendirmeye alınmamıştır.

\subsection{3. Çalışma Durumuna Göre Kariyer Geleceği Algısı ve İşveren Çekiciliği Algısına İlişkin Farklılıklar}

Çalışma durumuna göre kariyer geleceği algısının ve boyutları açısından anlamlı bir farklııı olmadığı görülmektedir $(p>0,05)$. Katılımcıların işveren çekiciliği boyutlarına "önemli" ifadesine yakın cevaplar verdikleri ve çalışma durumu göre işveren çekiciliği ve boyutları açısından anlamlı bir farklılık olmadığı anlaşılmıştır ( $p>0,05)$ (Tablo 15).

Tablo 15. Çalışma Durumuna Göre Kariyer Geleceği Algısı ve İşveren Çekiciliği Algısı Açısından t Testi Sonuçları

\begin{tabular}{|c|c|c|c|c|c|c|}
\hline & & & $\mathbf{n}$ & Ort. & ss & p \\
\hline \multirow{8}{*}{ 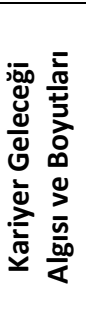 } & \multirow{2}{*}{ Kariyer Geleceği Algısı } & Çalışan & 56 & 3,90 & 0,45 & \multirow{2}{*}{0,54} \\
\hline & & Öğrenci & 305 & 3,87 & 0,44 & \\
\hline & \multirow{2}{*}{ Kariyer Uyumluluğu } & Çalışan & 56 & 3,96 & 0,55 & \multirow{2}{*}{0,24} \\
\hline & & Öğrenci & 305 & 3,90 & 0,53 & \\
\hline & \multirow{2}{*}{ Kariyer İyimserliği } & Çalışan & 56 & 3,96 & 0,60 & \multirow{2}{*}{0,87} \\
\hline & & Öğrenci & 305 & 3,97 & 0,57 & \\
\hline & \multirow{2}{*}{ Algılanan Bilgi } & Çalışan & 56 & 3,30 & 0,92 & \multirow{2}{*}{0,74} \\
\hline & & Öğrenci & 305 & 3,33 & 0,77 & \\
\hline
\end{tabular}


Tablo 15. Çalışma Durumuna Göre Kariyer Geleceği Algısı ve İşveren Çekiciliği Algısı Açısından t Testi Sonuçları (Devamı)

\begin{tabular}{|c|c|c|c|c|c|c|}
\hline & & & $\mathrm{n}$ & Ort. & SS & p \\
\hline \multirow{12}{*}{ 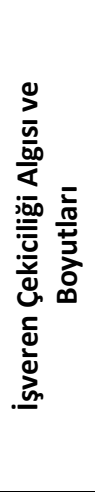 } & \multirow{2}{*}{ İşveren Çekiciliği Algısı } & Çalışan & 56 & 4,20 & 0,39 & \multirow{2}{*}{0,79} \\
\hline & & Öğrenci & 305 & 4,21 & 0,38 & \\
\hline & \multirow{2}{*}{ Sosyal Değer } & Çalışan & 56 & 4,17 & 0,71 & \multirow{2}{*}{0,49} \\
\hline & & Öğrenci & 305 & 4,22 & 0,67 & \\
\hline & \multirow{2}{*}{ Ekonomik Değer } & Çalışan & 56 & 4,17 & 0,58 & \multirow{2}{*}{0,44} \\
\hline & & Öğrenci & 305 & 4,22 & 0,61 & \\
\hline & \multirow{2}{*}{ Gelişim Değeri } & Çalışan & 56 & 4,17 & 0,63 & \multirow{2}{*}{0,20} \\
\hline & & Öğrenci & 305 & 4,08 & 0,73 & \\
\hline & \multirow{2}{*}{ Fayda Değeri } & Çalışan & 56 & 4,21 & 0,61 & \multirow{2}{*}{0,58} \\
\hline & & Öğrenci & 305 & 4,25 & 0,57 & \\
\hline & \multirow{2}{*}{ Uygulama Değeri } & Çalışan & 56 & 4,34 & 0,62 & \multirow{2}{*}{0,85} \\
\hline & & Öğrenci & 305 & 4,35 & 0,61 & \\
\hline
\end{tabular}

\subsubsection{Eğitim Durumuna Göre Kariyer Geleceği Algısı ve İşveren Çekiciliği Algısına İlişkin Farklılıklar}

Katılımcıların eğitim durumuna göre kariyer geleceği algıSı $(p=0,01)$ ve alt boyutu olan kariyer uyumluluğu $(p=0,00)$ açısından anlamlı bir fark olduğu anlaşılmaktadır. Tukey testi, farklıı̆ın lisansüstü eğitim durumuna sahip olan katılımcıların kariyer geleceği algılarının ön lisans eğitim durumundakilerden, kariyer uyumluluklarının ise lisans ve ön lisans eğitim durumundaki katılımcılardan fazla olması nedeniyle ortaya çıktığını göstermektedir. Eğitim durumunun kariyer iyimserliği ve iş piyasasına ilişkin algılanan bilgi açısından anlamlı bir farklılığa neden olmadığı anlaşılmıştır $(p>0,05)$.

Tablo 16. Eğitim Durumuna Göre Kariyer Geleceği Algısı ve İşveren Çekiciliği Algısı Açısından ANOVA Testi Sonuçları

\begin{tabular}{|c|c|c|c|c|c|c|}
\hline & & & $\mathrm{n}$ & Ort. & ss & $p$ \\
\hline \multirow{12}{*}{ 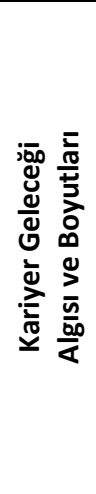 } & \multirow{3}{*}{ Kariyer Geleceği Algısı } & Ön lisans & 34 & 3,70 & 0,42 & \multirow{3}{*}{0,01} \\
\hline & & Lisans & 282 & 3,88 & 0,45 & \\
\hline & & Lisansüstü & 45 & 4,02 & 0,32 & \\
\hline & \multirow{3}{*}{ Kariyer Uyumluluğu } & Ön lisans & 34 & 3,64 & 0,62 & \multirow{3}{*}{0,00} \\
\hline & & Lisans & 282 & 3,93 & 0,53 & \\
\hline & & Lisansüstü & 45 & 4,05 & 0,40 & \\
\hline & \multirow{3}{*}{ Kariyer İyimserliği } & Ön lisans & 34 & 3,89 & 0,46 & \multirow{3}{*}{0,05} \\
\hline & & Lisans & 282 & 3,95 & 0,61 & \\
\hline & & Lisansüstü & 45 & 4,16 & 0,44 & \\
\hline & \multirow{3}{*}{ Algılanan Bilgi } & Ön lisans & 34 & 3,29 & 0,68 & \multirow{3}{*}{0,91} \\
\hline & & Lisans & 282 & 3,33 & 0,84 & \\
\hline & & Lisansüstü & 45 & 3,29 & 0,86 & \\
\hline \multirow{15}{*}{ 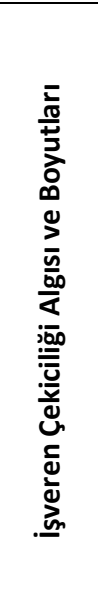 } & \multirow{3}{*}{ İşveren Çekiciliği Algısı } & Ön lisans & 34 & 4,16 & 0,37 & \multirow{3}{*}{0,65} \\
\hline & & Lisans & 282 & 4,21 & 0,39 & \\
\hline & & Lisansüstü & 45 & 4,23 & 0,36 & \\
\hline & \multirow{3}{*}{ Sosyal Değer } & Ön lisans & 34 & 4,09 & 0,72 & \multirow{3}{*}{0,55} \\
\hline & & Lisans & 282 & 4,22 & 0,70 & \\
\hline & & Lisansüstü & 45 & 4,18 & 0,58 & \\
\hline & \multirow{3}{*}{ Ekonomik Değer } & Ön lisans & 34 & 4,26 & 0,45 & \multirow{3}{*}{0,80} \\
\hline & & Lisans & 282 & 4,20 & 0,63 & \\
\hline & & Lisansüstü & 45 & 4,17 & 0,50 & \\
\hline & \multirow{3}{*}{ Gelişim Değeri } & Ön lisans & 34 & 4,05 & 0,70 & \multirow{3}{*}{0,19} \\
\hline & & Lisans & 282 & 4,09 & 0,71 & \\
\hline & & Lisansüstü & 45 & 4,29 & 0,59 & \\
\hline & \multirow{3}{*}{ Fayda Değeri } & Ön lisans & 34 & 4,10 & 0,59 & \multirow{3}{*}{0,39} \\
\hline & & Lisans & 282 & 4,24 & 0,57 & \\
\hline & & Lisansüstü & 45 & 4,26 & 0,63 & \\
\hline
\end{tabular}


Kariyer Geleceği Algılamalarının İşveren Çekiciliği Algısına Etkisi

Tablo 16. Eğitim Durumuna Göre Kariyer Geleceği Algısı ve İ̧veren Çekiciliği Algısı Açısından ANOVA Testi Sonuçları (Devamı)

\begin{tabular}{|c|c|c|c|c|c|c|}
\hline & & & $\mathrm{n}$ & Ort. & ss & $\mathrm{p}$ \\
\hline \multirow{3}{*}{ 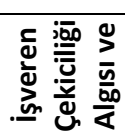 } & \multirow{3}{*}{ Uygulama Değeri } & Ön lisans & 34 & 4,35 & 0,66 & \multirow{3}{*}{0,84} \\
\hline & & Lisans & 282 & 4,36 & 0,59 & \\
\hline & & Lisansüstü & 45 & 4,30 & 0,67 & \\
\hline
\end{tabular}

Katılımcıların eğitim durumlarına göre işveren çekiciliği ve boyutları açısından anlamlı bir farklılık olmadığı anlaşıımıştır ( $p>0,05)$ (Tablo 16).

\section{Sonuç}

Kariyer geleceği algılamalarının işveren çekiciliği algısına etkisi belirlemek amacıyla yapılan bu çalışmada kariyer geleceği algısının işveren çekiciliğini etkilediği anlaşılmış ve araştırma hipotezi kabul edilmiştir. Kariyer geleceği algısının, işveren çekiciliği boyutlarından gelişim değeri, sosyal değer, fayda değeri ve uygulama değerini pozitif yönde, ekonomik değeri ise negatif yönde etkilediği anlaşılmaktadır. Kariyerini yetenekleri doğrultusunda planlayabilen, kariyeri hakkında iyimser tutum sergileyen, karşılaştığı kötü durumlar karşısında kendini kolaylıkla toparlayabilen, yeni görevler denemekten zevk alan ve bu görevlere kolaylıkla adapte olabilen bireylerin çalışma hayatında başarıı olmaları kaçınılmazdır. İşverenlerin, çalışanlara kendilerini geliştirme ve deneyim kazanma imkanları sunmalarının, işletme içerisinde mutlu bir çalışma ortamı sağlamalarının, topluma faydalı olacak ürün ve hizmetler üretmelerinin ve teorik olarak öğrenilen bilgileri iş hayatında uygulama fırsatı vermelerinin kariyer geleceği algısı düzeyi yüksek olan potansiyel çalışanları işletmeye çekebilmek açısından oldukça önemli olduğu anlaşılmaktadır. O'Cass vd. (2011)'nin çalışmasında da saptandığı için işveren çekiciliği açısından ekonomik boyut pozitif bir öncül veya sonuç olmayabilir. Bunun sebeplerinden biri de işveren markasının esas anlamının psikolojik değerlerde yer alması olabilir.

Kariyer geleceği algısı boyutlarının işveren çekiciliği algısına etkisini incelemek amacıyla yapılan analiz sonucunda, "kariyer uyumluluğu, işveren çekiciliğini etkilemektedir" şeklinde ifade edilen hipotez kabul edilmiştir. Kariyer uyumluluğunun, işveren çekiciliği boyutlarından sosyal değer, gelişim değeri ve fayda değerini pozitif yönde etkilediği görülmüştür. Destekleyici ve teşvik edici çalışma ortamına sahip olan, çalışanlara kendilerini geliştirme imkânı veren ve yenilikçi olan işletmelerin, değişime ayak uydurabilen, karşılaştığı engelleri kolaylıkla aşabilen, kariyer iyimserliği düzeyi yüksek potansiyel çalışanları işletmeye çekebilmeleri mümkün olacaktır. Kariyer geleceği algısının diğer bir boyutu olan kariyer iyimserliğinin, işveren çekiciliğini etkilediği görülmekte olup, "kariyer iyimserliği, işveren çekiciliğini etkilemektedir" şeklinde ifade edilen hipotez kabul edilmiştir. Kariyer iyimserliğinin, işveren çekiciliği boyutlarından gelişim değeri, uygulama değeri ve fayda değerini pozitif yönde, ekonomik değeri ise negatif yönde etkilediği anlaşılmaktadır. Karşılaştığı sorunlar karşııında çözüm odaklı olan, çabalarının karşıı̆ı̆ı alma inancı ve olumlu sonuçlar elde etme beklentisi ile çalışan bireylerin, işveren seçiminde kendini geliştirme imkânı tanıyan, öğrendiği bilgileri iş hayatında uygulamasını sağlayan ve yenilikçi bir yaklaşıma sahip işletmeleri tercih edebilecekleri söylenebilir. Kariyer iyimserliği yüksek bireylerin verilen ücret, statü ve iş güvencesi gibi ekonomik çekicilik boyutlarını daha az önemsedikleri söylenebilir. İş piyasasına ilişkin algılanan bilgi boyutunun, işveren çekiciliğine anlamlı bir etkisinin bulunmadığı anlaşılmıştır. Bu nedenle "iş piyasasına ilişkin algılanan bilgi, işveren çekiciliğini etkilemektedir" şeklinde ifade edilen hipotez reddedilmiştir.

İşverenlerin, çalışan seçiminde potansiyel çalışanların hangi işveren çekiciliği boyutlarına önem verdiklerini bilmeleri, işe alım sürecinin işletmeler açısından verimli ve etkin geçmesini sağlayacaktır. Araştırma doğrultusunda, kariyer geleceği algısı yüksek olan bireylerin; yüksek ücret, iş güvencesi, yükselme gibi ekonomik unsurlardan ziyade, çalıştığı işletmede ve iş ortamında kendisi iyi hissedebilecekleri, yaptığı işlerin karşılığında üstleri tarafından takdir edilecekleri, çalışma arkadaşları ve yöneticileri ile iyi ilişkilere sahip olacakları, kendini geliştirebilecekleri ve öğrendiği bilgileri çalışma hayatında uygulayabilecekleri işletmeleri çekici buldukları görülmektedir. 
Kariyer geleceği algısı açısından kuşaklar arasında bir farklııı bulunmadığı anlaşılmıştır. Ancak işveren çekiciliği açısından $Y$ kuşağının, çalışma hayatı süresince kendini geliştirmeye, üstleri tarafından takdir edilmeye ve kariyer gelişim hedefleri doğrultusunda işveren tercih etmeye daha çok önem verdiği görülmektedir. Y ve Z kuşakları, çalışmayı tercih edecekleri işletmelerde en fazla önemi, fayda değeri ve uygulama değerine vermektedirler. $Y$ ve $Z$ kuşaklarının çalışma hayatındaki rolünün gün geçtikçe arttığı düşünüldüğünde, işletmelerin çalışanlarının yaratıcılığına önem vermeleri, yenilikçi uygulamalar geliştirmeleri, çalışanlara öğrendiği bilgileri uygulama fırsatı sunmaları ve çalışanlara aidiyet hissi sağlayabilmeleri, bu kuşaklara dahil olan potansiyel çalışanların işletmeye çekilmesi adına oldukça önem taşımaktadır. Araştırmada, cinsiyete göre kariyer geleceği algısı ve işveren çekiciliği açısından anlamlı bir farklılık olduğu görülmüştür. Kadınların kariyer geleceği algısı ve alt boyutu olan kariyer uyumluluğu düzeylerinin erkeklere göre daha yüksek olduğu anlaşılmıştır. Kadınların çalışma ortamına erkeklere göre daha çabuk uyum sağlayabilmeleri ve değişime açık olmaları bu farklılığın nedeni olarak görülebilir. Kadınların sosyal değer boyutuna erkeklerden daha fazla önem vermesi bu duruma kanıt niteliğindedir. Diğer bir farklılık ise, kadınların uygulama değeri boyutlarına erkeklere göre daha fazla önem vermesidir. Sosyal sorumluluk faaliyetleri gerçekleştiren, müşteri memnuniyetine önem veren, çalışma arkadaşları ve yöneticiler arasında iyi ilişkilerin bulunduğu işletmelerin kadın çalışanları çekme konusunda daha başarılı olacağı söylenebilir. Bu açıdan birçok çalışmada da potansiyel adayların cinsiyetlerine göre de beklentilerinin incelenmesi ve dikkate alınması vurgulanmıştır (Terjesen vd., 2007). Katılımcıların kariyer geleceği algılarının eğitim seviyelerine paralel olarak arttığı görülmektedir. Eğitim seviyesi arttıkça; değişimlere adapte olma, yeni talepleri karşılayabilme, kötü durumlarda kendini toparlayabilme gibi tutumların arttığı anlaşılmıştır.

Araştırma ağırlıklı olarak bir devlet üniversitesinde öğrenim görmekte olan öğrenciler üzerinde gerçekleştirilmiştir. Gelecekte yapılacak araştırmalarda; araştırma evreni ve örneklemi genişletilerek, kariyer geleceği algısının farklı kültürel özelliklerde incelenmesi ve bireylerin kariyer geleceği algılarını geliştiren faktörlerin incelenmesi önerilmektedir. Bununla birlikte katılımcılara, çalışmayı arzu ettikleri ideal işveren değerlendirmesi yaptırılarak bu çerçevede işveren çekiciliğinin ölçülmesi söz konusu olabilir.

\section{Beyan ve Açıklamalar (Disclosure Statements)}

1. Bu çalışmanın yazarları, araştırma ve yayın etiği ilkelerine uyduklarıı kabul etmektedirler (The authors of this article confirm that their work complies with the principles of research and publication ethics).

2. Yazarlar tarafından herhangi bir çıkar çatışması beyan edilmemiş̧ir (No potential conflict of interest was reported by the authors).

3. Bu çalışma, intihal tarama programı kullanılarak intihal taramasından geçirilmiştir (This article was screened for potential plagiarism using a plagiarism screening program).

\section{Son Notlar}

1. Bu çalışma, Berk Ozcinar'ın yüksek lisans tezinden türetilmiştir.

\section{Kaynaklar}

Aspinwall, L. G., Richter, L., \& Hoffman III, R.R. (2001). Understanding how optimism works: An examination of optimists' adaptive moderation of belief and behavior. E. C. Chang (Ed.), Optimism \& pessimism: Implications for theory, research, and practice (p. 217-238). American Psychological Association.

Backhaus, K., \& Tikoo, S. (2004). Conceptualizing and researching employer branding. Career Development International, 9(5), 502-505

Barrow, S., \& Mosley, R. (2011). The employer brand: Bringing the best of brand management to people at work. John Wiley \& Sons 
Berthon, P., Ewing, M., \& Hah, L. L. (2005). Captivating company: Dimensions of attractiveness in employer branding. International Journal of Advertising, 24(2), 151-172.

Crane, F. G., \& Crane, E. C. (2007). Dispositional optimism and entrepreneurial success. The Psychologist-Manager Journal, 10(1), 13-25.

Gunkel, M., Schlaegel, C., Langella, I. M. \& Peluchette, J. V. (2010). Personality and career decisiveness: An international empirical comparison of business students' career planning. Personnel Review, 39(4), 503-524.

Highhouse, S., Lievens, F., \& Sinar, E. F. (2003). Measuring attraction to organizations. Educational and Psychological Measurement, 63(6), 986-1001.

Jiang, T., \& lles, P. (2011). Employer-brand equity, organizational attractiveness and talent management in the Zhejiang private sector, China. Journal of Technology Management in China, 6(1), 97-110

Kalafat, T. (2012). Kariyer geleceği ölçeği kargel Türk örneklemi için psikometrik özelliklerinin incelenmesi. Türk Psikolojik Danışma ve Rehberlik Dergisi, 4(38), 169-179

Kaliprasad, M. (2006). The human factor i: Attracting, retaining, and motivating capable people. Cost Engineering, 48(6), 20-26.

Kalafat, T. (2018). Psychological resilience and self-esteem related components on career adaptation and career optimism. The International Journal of Human and Behavioral Science, 4(2), 31-41.

Karadaş, A., Duran, S., \& Kaynak, S. (2017). Hemşirelik öğrencilerinin kariyer planlamaya yönelik görüşlerinin belirlenmesi. SDÜ Sağlık Bilimleri Dergisi, 8(1), 1-8.

Mahroum, S. (2000). Highly skilled globetrotters: Mapping the international migration of human capital. $R \& D$ Management, 30(1), 23-32.

Manpower Group Talent Shortage 2020, https://go.manpowergroup.com/hubfs/MPG_WhatWorkersWant_2020.pdf?hsLang=en_(Erişim Tarihi: 22 Ağustos 2020).

McLennan, B., Mcllveen, P., \& Perera, H. N. (2017). Pre-service teachers' self-efficacy mediates the relationship between career adaptability and career optimism. Teaching and Teacher Education, 63, 176-185.

Mcllveen, P., Beccaria, G., \& Burton, L. J. (2013). Beyond conscientiousness: Career optimism and satisfaction with academic major. Journal of Vocational Behavior, 83(3), 229-236.

O'Cass, A., Schlager, T., Bodderas, M., Maas, P., \& Cachelin, J. L. (2011). The influence of the employer brand on employee attitudes relevant for service branding: An empirical investigation. Journal of Services Marketing, 25(7), 497-508.

Öksüz, B. (2012). İşveren markası yönetimi sürecinde iletişimin önemi. Selçuk Üniversitesi Iletişim Dergisi, 7(2), $14-31$.

Rottinghaus, P. J., Day, S. X., \& Borgen, F. H. (2005). The career futures inventory: A measure of career-related adaptability and optimism. Journal of Career Assessment, 13(1), 3-24.

Rottinghaus, P. J., \& Van Esbroeck, R. (2011). Improving person-environment fit and self-knowledge. P. J. Hartung \& L. M. Subich (Eds.), Developing self in work and career: Concepts, cases, and contexts (p. 35-52), American Psychological Association.

Santilli, S., Marcionetti, J., Rochat, S., Rossier, J., \& Nota, L. (2016). Career adaptability, hope, optimism, and life satisfaction in Italian and Swiss adolescents. Journal of Career Development, 44(1), 62-76.

Savickas, M. L. (1997). Career adaptability: An integrative construct for life-span, life-space theory. The Career Development Quarterly, 45(3), 247-259.

Savickas, M. L., \& Porfeli, E. J. (2012). Career adapt-abilities scale: Construction, reliability, and measurement equivalence across 13 countries. Journal of Vocational Behavior, 80(3), 661-673.

Scheier, M. F., Carver, C. S. \& Bridges, M. W. (1994). Distinguishing optimism from neuroticism (and trait anxiety, selfmastery, and self-esteem): A reevaluation of the life orientation test. Journal of Personality and Social Psychology, 67(6), 1063-1078.

Scheier, M. F., \& Carver, C. S. (1985). Optimism, coping, and health: Assessment and implications of generalized outcome expectancies. Health Psychology, 4(3), 219-247.

Seligman, M. E. (1998). Building human strength: Psychology's forgotten mission. APA Monitor, 29(1), 2.

Seligman, M. E. (2006). Learned optimism: How to change your mind and your life. Vintage Books.

Siyez, D. M., \& Belkıs, Ö. (2016). Üniversite öğrencilerinde kariyer iyimserliği ve uyumluluğu ile toplumsal cinsiyet algıSı arasındaki ilişki. Eğitim ve Öğretim Araştırmaları Dergisi, 5(4), 279-285. 
Sökmen, A., \& Aydıntan, B. (2016). Kariyer geleceği algısının iş tatmini ve işten ayrılma niyetine etkisi: Bir kamu kurumunda araştırma. İşletme Araştırmaları Dergisi, 8(3), 251-263.

Sullivan, J. (2004). Eight elements of a successful employment brand. ER Daily, 23(2), 501-517.

Super, D. E. (1955). Dimensions and measurement of vocational maturity. Teachers College Record, 57, $151-163$.

Super, D. E. (1980). A life-span, life-space approach to career development. Journal of Vocational Behavior, 16(3), 282298.

Super, D. E. \& Knasel, E. G. (1981). Career development in adulthood: Some theoretical problems and a possible solution. British Journal of Guidance and Counselling, 9(2), 194-201.

Terjesen, S., Vinnicombe, S., \& Freeman, C. (2007). Attracting generation Y graduates. Career Development International. Career Development International, 12(6), 504-522.

Tladinyane, R., \& Van der Merwe, M. (2015). Age and race differences on career adaptability and employee engagement amongst employees in an insurance company. Journal of Governance and Regulation, 4(4), 720-726.

Turban, D. B. (2001). Organizational attractiveness as an employer on college campuses: An examination of the applicant population. Journal of Vocational Behavior, 58(2), 293-312.

Zacher, H., Ambiel, R. A., \& Noronha, A. P. P. (2015). Career adaptability and career entrenchment. Journal of Vocational Behavior, 88, 164-173.

Zorver, C. E., \& Owen, F. K. (2014). Developing a career adaptability and optimism scale. Journal of Human Sciences, 11(2), 314-331. 
This Page Intentionally Left Blank 